\title{
Cyclo-, Magneto-, and Bio-Stratigraphic Constraints on the Duration of the CAMP Event and its Relationship to the Triassic-Jurassic Boundary
}

\author{
Paul E. Olsen ${ }^{1}$, Dennis V. Kent ${ }^{2}$, Mohammed Et-Touhami ${ }^{3}$, John Puffer ${ }^{4}$
}

Early Mesozoic tholeiitic flood basalts of the Central Atlantic Magmatic Province (CAMP) are interbedded throughout much of their extent with cyclical lacustrine strata, allowing Milankovitch calibration of the duration of the extrusive episode. This cyclostratigraphy extends from the Newark basin of the northeastern US, where it was first worked out, to Nova Scotia and Morocco and constrains the outcropping extrusive event to less than $600 \mathrm{ky}$ in duration, beginning roughly 20 ky after the Triassic-Jurassic boundary, and to within one pollen and spore zone and one vertebrate biochron. Based principally on the well-known Newark astronomically calibrated magnetic polarity time scale with new additions from the Hartford basin, the rather large scatter in recent radiometric dates from across CAMP ( $>10$ m.y. ), centering on about $\sim 200$ m.y., is not likely to be real. Rather, the existing paleomagnetic data from both intrusive and extrusive rocks suggest emplacement of nearly all the CAMP within less than 3 m.y. of nearly entirely normal polarity. The very few examples of reversed magnetizations suggest that some CAMP activity probably occurred just prior to the Triassic-Jurassic boundary. Published paleomagnetic and $40 \mathrm{Ar} / 39 \mathrm{Ar}$ data from the Clubhouse Crossroads Basalt are reviewed and with new paleomagnetic data suggest that alteration and possible core misorientation could be responsible for the apparent differences with the CAMP. The Clubhouse Crossroads Basalt at the base of the Coastal Plain of South Carolina and Georgia provides a link to the volumetrically massive volcanic wedge of seaward dipping reflectors present in the subsurface off the southeastern US that may be part of the same igneous event, suggesting that the CAMP marks the formation of the oldest Atlantic oceanic crust.

\section{INTRODUCTION}

The Early Mesozoic age Central Atlantic Magmatic Province (CAMP) of eastern North America, southwestern Europe, West Africa, and South America (Figure 1) is possibly the largest known example of a continental flood The Central Atlantic Magmatic Province: Insights from Fragments of Pangea Geophysical Monograph 136 Copyright 2003 by the American Geophysical Union 10.1029/136GM02
${ }^{1}$ Lamont-Doherty Earth Observatory of Columbia University, Rt. 9W, Palisades, NY 10964, USA

2Department of Geological Sciences, Rutgers University, Piscataway, NJ 08854-8066, USA, and Lamont-Doherty Earth Observatory of Columbia University, Rt. 9W, Palisades, NY 10964, USA

3LGVBS, Département des Sciences de la Terre, Université Mohamed Premier, 60, 000 Oujda, Morocco, and Lamont-Doherty Earth Observatory of Columbia University, Rt. 9W, Palisades, NY 10964, USA

4 Department of Geological Sciences, Rutgers University, 195 University Avenue, Boyden 407, Newark, N.J. 07102 


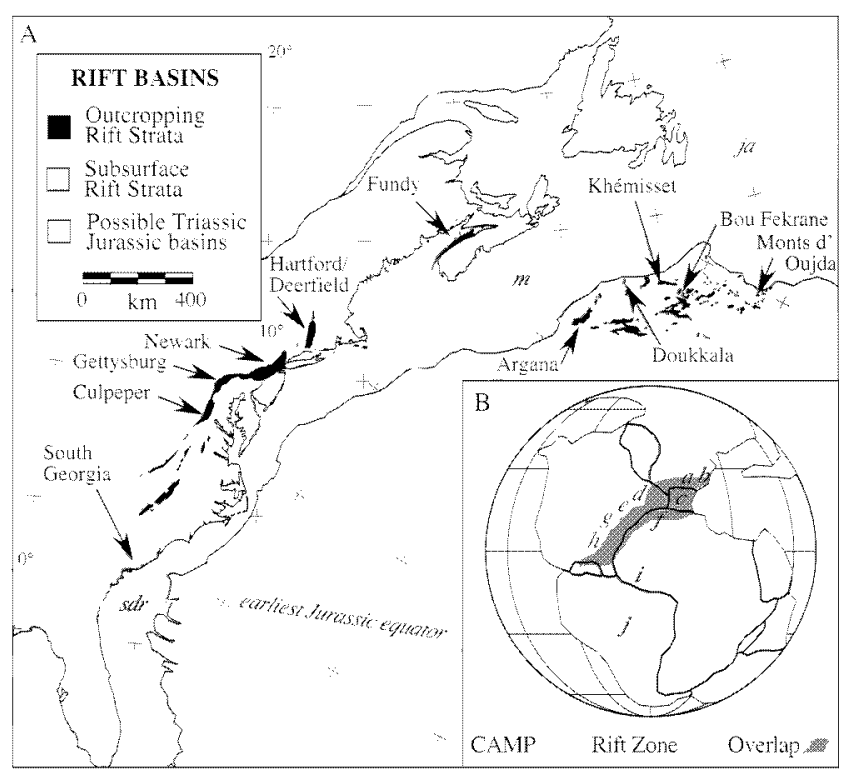

Figure 1. Distribution of rift basins in eastern North America and Morocco and the distribution of the CAMP. A, Eastern North American rift basins. Abbreviations are: ja, Jeane d'Arc basin of the Grand Banks area; $m$, Mohican basin on the Scotian Shelf; sdr,seaward dipping reflectors an the southeastern United States continental margin. B, Pangea in the earliest Jurassic showing the distribution of rifts, the Central Atlantic Magmatic Province(CAMP) and areas discussed in text. Abbreviations are: a, pyroclastics and ?sills of the Aquitaine basin of southwestern France; b, alkali basalt pyroclastics and flows in Provence, c, the Ecrins-Pelvoux ofthe external massif of the Alps, France; d, flows in Iberia, including the Pyrennes; e, flows in the basins on the Grand Banks region, Canada; $f$, Fundy basin area of the Maritime provinces, Canada; g, flows in Morocco, Tunisia, and Algeria; $h$, flows in the major rifts in the eastern United States; $i$, flows in the South Georgia rift and the offshore seaward dipping reflectors; $j$, ultrabasic layered plutons and dikes of Liberia, Mali, and Senegal; $k$, flows of Brazil.

basalt. Indeed, according to Marzoli et al. (1999), this Central Atlantic Magmatic Province (CAMP) may be the largest large igneous province (LIP) of all, extending over $7 \times 10^{6} \mathrm{~km}^{2}$ prior to the formation of the Atlantic and covering significant continental portions of at least four presentday tectonic plates. While there has been tremendous progress in constraining the duration of this huge volcanic event (e.g. Deckart et al., 1997; Marzoli et al., 1999; Hames et al., 2000 ), existing radiometric dating techniques have not yet been able to produce reproducible (intra-laboratory) and internally consistent dates within the extremely narrow precision limits needed to understand the possible relationship of the CAMP to the Triassic-Jurassic mass extinctions, climate change, and formation of the earliest Atlantic oceanic crust (e.g. Turrin, 2000). Indeed, the present stated analytical uncertainties are one to two orders of magnitude better than their demonstrable accuracy as judged by independent geological criteria.

In this paper we elaborate on the cyclostratigraphic constraints on the duration of the CAMP lavas, described by Olsen et al. (1996b) using new cyclostratigraphic, biostratigraphic and igneous geochemical data from Nova Scotia and Morocco. We provide new paleomagnetic limits on the duration of the intrusive and extrusive parts of the CAMP using the Newark basin astronomically calibrated geomagnetic polarity timescale (Kent and Olsen, 2000a; Olsen and Kent, 1999), updated using new data from the Hartford basin (Kent and Olsen, 1999b). We provide new geochemical data from Moroccan basalts and new paleomagnetic data from the Clubhouse Crossroads Basalt, and we place all of the constraints on the duration of the CAMP basalts within the framework of the Triassic-Jurassic massextinction.

\section{CYCLOSTRATIGRAPHIC CONSTRAINTS}

Based primarily on the results of the Newark Basin Coring Project and the cores recovered by the Army Corps of Engineers, the cyclostratigraphy of sedimentary strata of the extrusive zone of the Newark basin was described and interpreted as being controlled by Milankovitch climate cycles (Olsen et al., 1996b) (Figure 2). Because it is known from continuous core, the Newark basin sections provides a basis of comparison for the other rift basin sections, and the cyclostratigraphy and its interpretation is reviewed below (Figure 3) (Kent et al., 1995; Olsen et al., 1996b; Olsen and Kent, 1999; Kent and Olsen, 2000a). We have recently also produced a preliminary cyclostratigraphy and paleomagnetic reversal stratigraphy for the lower half of the post-extrusive Portland Formation of the Hartford basin (Figure 3) that places an upper bound on the duration of the normal polarity zone encompassing the CAMP lavas (Kent et al., 1999b).

\subsection{Newark Basin}

A permeating hierarchy of sedimentary cycles that reflect changes in lake depth characterizes the predominately lacustrine portions of the Newark basin section. This cyclicity is apparently controlled by Milankovitch climate cycles in precipitation and evaporation (Figure 2). While the classic section for this cyclicity is the Lockatong Formation (Van Houten, 1962, 1964, 1980), it has also proved prevalent in the underlying upper part of the Stockton Formation (Raven Rock Member: Olsen and Kent, 1999; Kent and Olsen, 2000a), and the overlying Passaic Formation and within and above the extrusive zone itself (Olsen, et al., 1996a, 1999). Indeed similar cyclicity (with variations) typify the sediments within and around the extrusive zone of all of the Central Atlantic Margin Basins (CAM) basins (Olsen, 1997; Olsen and Kent, 2000). 


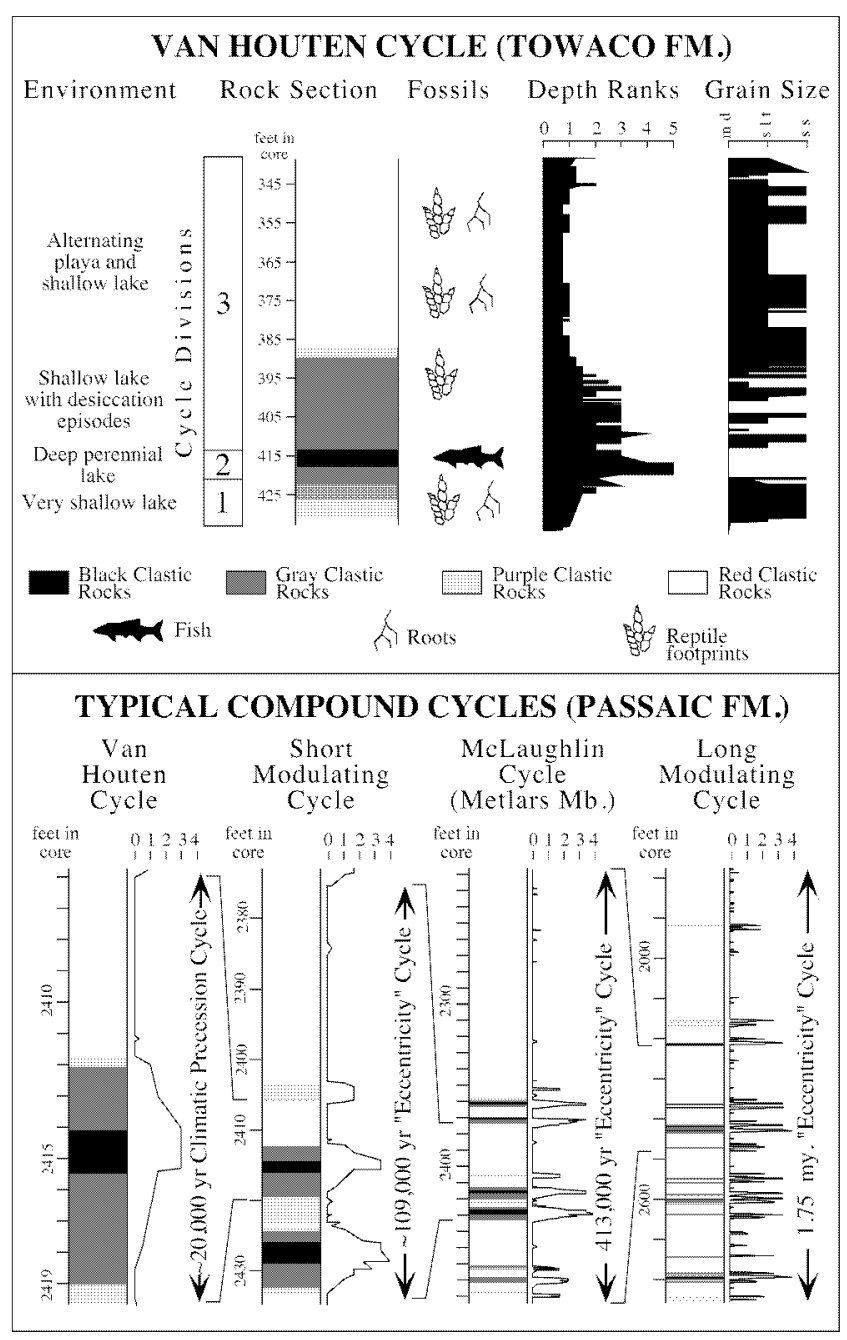

Figure 2. Van Houten and modulating (compound) cycles. Modified from Olsen et al. (1996). Depth Ranks is an ordination of sedimentary facies along a very shallow (0) to very deep (5) relative lake depth gradient.

The most obvious outcrop-scale sedimentary cycle in the Newark basin section is the Van Houten lake level cycle, named by Olsen (1986) after its discoverer (Van Houten, 1962, 1964, 1969) (Figure 2). Each Van Houten cycle consists of a transgressive division (1), a high-stand division (2), and a regressive and low-stand division (3), produced by the rise and fall of lakes under control of the $\sim 20 \mathrm{ky}$ cycle of climatic precession. Vertical sequences of Van Houten cycles show a hierarchical variation of expression making up three larger scale lithological cycles attributed to modulation by a hierarchy of the three main cycles of eccentricity: the short modulating lithological cycle $(\sim 100$ ky eccentricity cycle), the McLaughin lithological cycle (404 ky eccentricity cycle), and the long modulating cycle $(\sim 2$ m.y. eccentricity cycle) (Figure 2 ). These modulating cycles are expressed as changes in the degree of development or absence of various desiccation features. As interpreted by Olsen and Kent (1996, 1999), high amplitude climatic precession cycles, occurring at times of maximum eccentricity, tend to have produced Van Houten cycles with the least desiccation features, a division 2 with very well developed black, laminated shales preserving whole fish, and overall a more gray and black color, even in division 3. In contrast, low amplitude climatic precession cycles, occurring during times of low eccentricity, have pervasive desiccation features, a poorly developed division 2 , itself with desiccation features, and an overall red color, sometimes with evaporite pseudomorphs. The best developed Van Houten cycles, with the best developed black shales, thus occur during the overlap of maxima between the three eccentricity cycles and their lithological counterparts. It is consistent modulation of the expression of the Van Houten cycles that is the fingerprint of the control by Milankovitch climate cycles.

The physical stratigraphy of the lacustrine strata of the Newark basin extrusive zone has been described by Olsen et al. (1996b) (Figure 4). The uppermost Passaic Formation and overlying units are characterized by Van Houten cycles that are two to six times the thickness of those in the older strata, but still show the same kind of hierarchy of modulating cycles as in the rest of the basin lacustrine section. These modulating cycles, as well as the basic Van Houten cycles are what permit the cyclostratigraphic calibration of the duration of the extrusive zone as well as demonstrate the synchronicity in different basins of the flow sequences themselves.

Olsen (1984) and Olsen and Kent (1996) developed a quasi-quantitative classification of the sedimentary facies within Van Houten cycles called depth ranks that permits a single-variable description of the inferred water depth, and hence numerical analysis (e.g. Olsen and Kent, 1996, 1999). A microlaminated, usually black, shale with no signs of desiccation and common preservation of fossil fish is interpreted as the deepest water facies (rank 5). In contrast, a usually red massive mudstone with abundant superimposed desiccation cracks is interpreted as the driest facies (rank 0 ). The depth rank curve for the uppermost Passaic, extrusive zone strata, and overlying strata is shown in Figure 4.

Taken together with the uppermost Passaic Formation, the depth rank curve of the sedimentary formations of the extrusive zone and Boonton marks out a clear hierarchical pattern consisting of about three McLaughlin cycles (Figure 4). This pattern of cyclicity is clearly a continuation of the overall pattern seen in the Passaic and Lockatong formations, albeit with an increase in accumulation rate. The pattern of short modulating and Van Houten cycles is clearest in cores in the Towaco and Boonton formations. Van Houten cycles and short modulating cycles are muted 


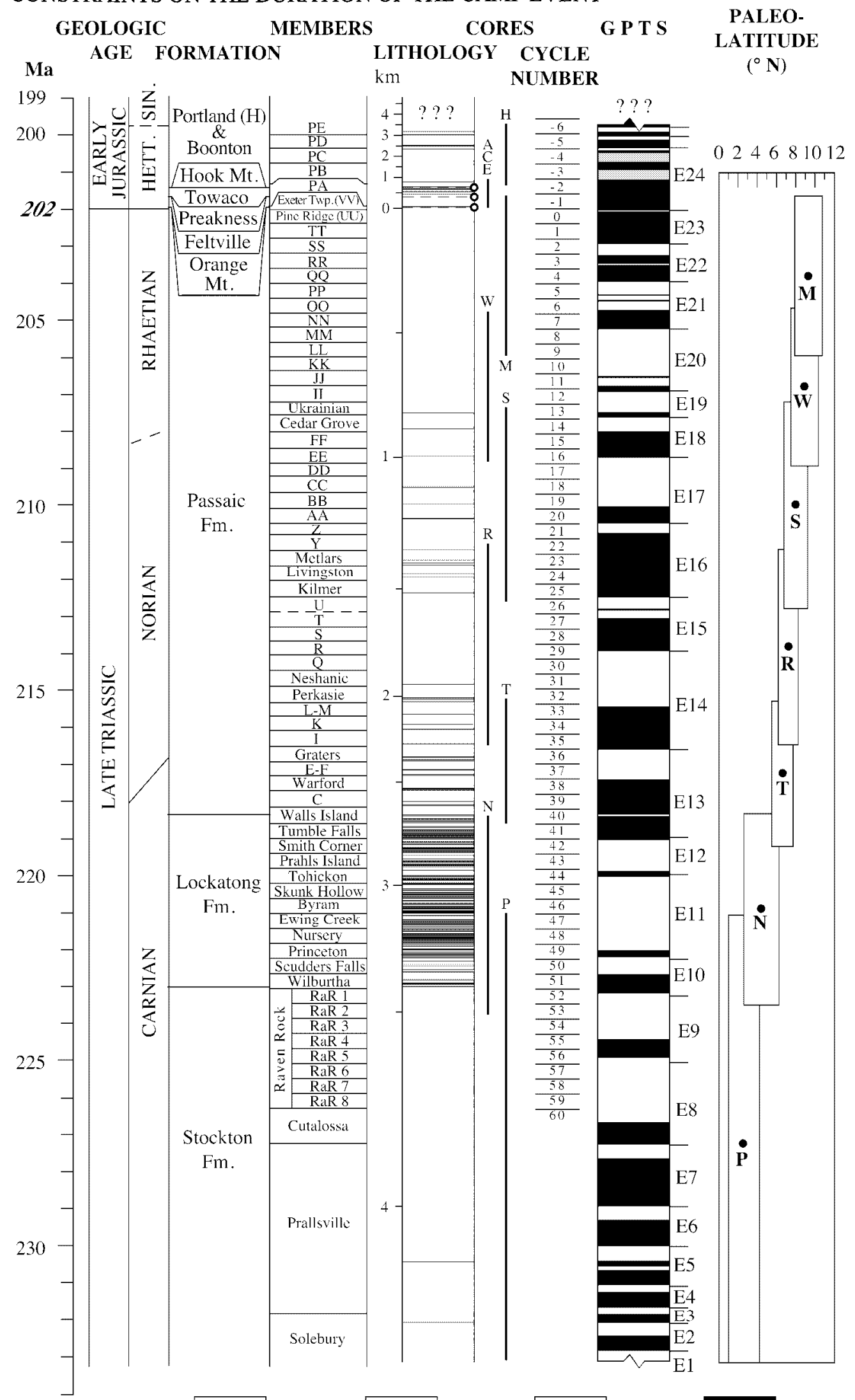

red clastic rocks purple clastic rocks 


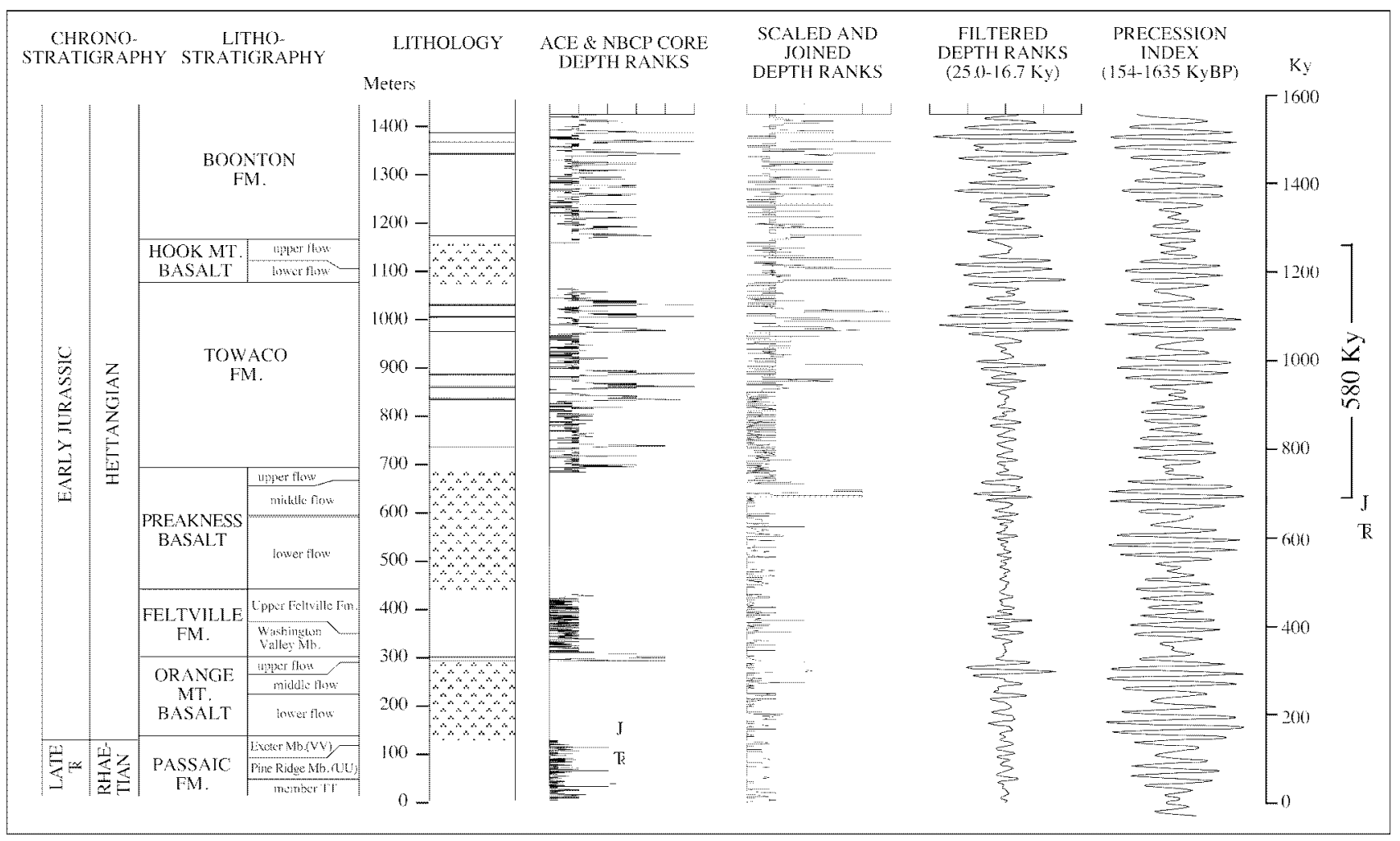

Figure 4. Cyclostratigraphic calibration of the Triassic-Jurassic boundary and succeeding extrusive zone flows and interbedded and overlying sedimentary strata (adapted from Olsen et al., 1996b). Depth ranks are a numerical classification of sedimentary facies sequences in order of increasing interpreted relative water depth (see Olsen and Kent, 1996). Comparison of the depth rank curves with an arbitrary segment of a precession index curve indicates that it is not necessary to assume any significant time is represented by the lava flow formations themselves and that the entire flow sequence as probably deposited during an interval of less than $600 \mathrm{ky}$. Note also that the Triassic-Jurassic boundary (correlated to the Jacksonwald syncline by Magneto- and lithostratigraphy) lies about 20 ky below the Orange Mountain basalt. The depth rank record from the strata above the Preakness Basalt is based on the ACE cores, while that from the Passaic and Feltville Formations are based on the Martinsville no. 1 core of the NBCP.

in the Feltville Formation, except at its base where there are two very well developed limestone-bearing Van Houten cycles. Correlative sections of the uppermost Passaic Formation with much better expressed cyclicity provide supplementary data, especially critical for the Triassic-Jurassic boundary (Figure 5).
Because of uncertainties in the chaotic behavior of the planets, the recession of the moon, and dynamics of the Earth's interior, it is not yet possible to construct target curves of insolation for direct astronomical tuning of the Newark basin depth rank series (Laskar, 1999). However it is possible to compare the depth rank curve with arbitrary

Figure 3. Time scale for the Late Triassic and Early Jurassic based on geomagnetic polarity time scale (GPTS) and astronomical calibration from the Newark Basin Coring Project (Kent and Olsen, 1999a; Olsen and Kent, 1999), the ACE cores (Fedosh and Smoot, 1988; Olsen et al., 1996), and preliminary results from the Hartford basin (Kent and Olsen, 1999b). Biostratigraphic data from Huber et al. (1996), Lucas and Huber (2002), Cornet (1977), and Cornet and Olsen (1985). For the GPTS, black is normal polarity, white is reversed polarity, and gray represents intervals for which there is incomplete sampling (Hartford basin section only). Abbreviations are: ACE, ACE (Army Corps of Engineers) cores; H, Hartford basin section; HETT., Hettangian; L.V.A., Land Mammal Ages; M, Martinsville (NBCP) core; N, Nursery (NBCP) core; P, Princeton (NBCP) cores; R, Rutgers (NBCP) cores; S, Somerset (NBCP) cores; SIN., Sinemurian; T, Titusville (NBCP) core; W, Weston Canal (NBCP)cores. Cycle number refers to the 404 ky cycle of eccentricity with lines placed at the calculated minima. 
segments of appropriate length of insolation curves for the last 10 m.y. (Laskar, 1990). To do this we first assume that the Van Houten cycle does indeed represent the $\sim 20 \mathrm{ky}$ climatic precession cycle. Second we use Fourier analysis to quantitatively determine the thickness period of the Van Houten cycles for each sedimentary formation. The depth rank curves in thickness are then scaled to time independently for each formation assuming a $\sim 20 \mathrm{ky}$ duration for the average Van Houten cycles. Then using the largest envelope of the curves, they are matched to an insolation curve, constrained by phase relationships of the two curves.

It is apparent that the stacked and scaled depth rank sections resemble three successive $404 \mathrm{ky}$ cycles. The highest amplitude parts of these cycles occur in the lower Feltville and uppermost Passaic formations, the middle to upper Towaco. Formation, and finally the upper Boonton Formation, as represented in the cores. Detailed comparison of the depth rank curves to different insolation curves suggests that it not necessary to assume that the basalt flows in the exposed Pangean basins represent any significant time, although they could represent as much as $100 \mathrm{ky}$ in total, depending on the insolation curve chosen (Olsen et al., 1996a). Olsen et al. (1996a) thought that about $40 \mathrm{ky}$ was represented above the Triassic-Jurassic boundary, but examination of new outcrops in the Jacksonwald syncline of the southwestern Newark basin suggests that value should be closer to $20 \mathrm{ky}$, as only one Van Houten cycle is represented (Olsen et al., 2002a) (Figures 4, 5).

As noted by Olsen et al. (1996a), for really major gaps to be represented by the basalt flows, the cyclostratigraphy of the various formations would either have to be offset from each other by multiples of the 404 ky cycles to maintain the phase relationships with the insolation curves, or the fundamental cyclicity itself would have to be misidentified, neither of which seem likely. No other central Atlantic margin rift basin is known in as much stratigraphical detail as the Newark basin; however specific parts of other basins are known in enough detail to compare with parts of the Newark basin depth rank curve for the extrusive zone.

\subsection{Other Exposed Rift Basins in the US}

Sedimentary strata immediately below, and interbedded with, basalts in other basins in the United States, show a pattern of cyclicity very similar to that in the Newark basin. Generally Van Houten cycles are minimally several meters thick (10->100 m thick) and black laminated shales are commonly present in the better expressed cycles. The sedimentary strata within and above the extrusive zone is known in the most detail in the Hartford basin. From what is available in outcrop, and sparse core, the Hartford basin section appears cyclostratigraphically extremely similar to the Newark basin. Intervals of core are available for the lower Portland Formation (Pienkowski and Steinen, 1995) and it is clear that the stratigraphy of the lowermost Portland is nearly identical to the lower Boonton Formation. However the similarity to the Newark basin stratigraphy is most clearly seen in the middle to upper East Berlin Formation, which is virtually identical to the middle and upper Towaco Formation (Figure 5). Long sections through the underlying Shuttle Meadow Formation are unknown, but it is clear that two limestone-bearing Van Houten Cycles are present at the base of the formation, very similar to the two at the base of the Feltville Formation. In addition, there is at least one gray sequence below the oldest basalt (Heilman, 1987; Olsen et al., 2002c), but otherwise the pre-basalt sequence in the same area consists primarily of red and brown sandstone and conglomerite (Figure 5). Overall the depth rank curve of the available outcrops and cores is extremely close to that of the Newark basin, and hence the basalt flow formations appear to have erupted in synchrony. Although the section is far from completely known, there is very little evidence suggesting that that the basalt formations themselves represent significant time (e.g. greater than a few tens of thousands of years). The cyclostratigraphic correlations are in complete agreement with the geochemistry of the three distinctive basalt formations in each basin (Puffer and Philpotts, 1989) and the distinctive paleomagnetic excursion in the lower Preakness and Holyoke basalts (Prevot and McWilliams, 1989).

The Deerfield basin has a stratigraphy that is closely comparable to that of the Hartford basins, except that only one basalt flow formation is present (the Deerfield Basalt). The only part of the Deerfield section that is known in detail is the $180 \mathrm{~m}$ section continuously exposed at Turners Falls in the lower Turners Falls Formation in contact with the underlying Deerfield Basalt. The cyclostratigraphy and depth rank section of this outcrop is very similar to the middle East Berlin and the middle and lower Towaco formations, and based on cyclostratigraphy, this section represents about 300 to $345 \mathrm{ky}$. Thus, the Deerfield Basalt correlates extremely closely with the Holyoke Basalt of the Hartford basin and the Preakness Basalt of the Newark basin, which is in agreement with available geochemical and paleomagnetic data (Puffer and Philpotts, 1988; Prevot and McWilliams, 1989). No other basalt units are present in the Deerfield basin. The Fall River beds below the Deerfield basalt resemble the upper Shuttle Meadow Formation, but there is no sign of the lower two limestone-bearing Van Houten cycles typical of that formation. Based on their absence and the very abrupt change in facies between the underlying Sugarloaf Formation and an apparent angular relationship with the Fall River beds of Olsen et al. (1992), Smoot (in Olsen, 1997) and Hubert and Dutcher (1999) suggest that there is a minor unconformity. In addition, there is virtually no exposure for hundreds of meters above the 
beds exposed at Turners Falls and there is no basalt present where one would be expected on the basis of cyclostratigraphy. Cornet (1977) argued that there was evidence of an unconformity within the Turners Falls Formation equivalent to the Hampden Basalt of the Hartford basin. However, as discussed by Olsen et al. (1992), this evidence is based on pollen, from beds not demonstrably in superposition, and from levels well above where the equivalent of the Hampden Basalt should be.

The Pomperaug basins is situated between the Newark and Hartford basins. The strata between the "East Hill basalt" and "Orenaug basalt" has two limestone-bearing Van Houten cycles at its base, again very similar to the Feltville Formation of the Newark basin and the Shuttle Meadow Formation of the Hartford basin (LeTourneau and Huber, 2001). Hence, a correlation between the "East Hill basalt" and the Orange Mountain Basalt and the Talcott Basalt is suggested.

Nothing in detail is known about the cyclostratigraphy of the one basalt flow formation (Aspers Basalt) in the Gettysburg basin because of poor outcrop.

Poor outcrop and relative lack of study also limits what is known about the Culpeper basin extrusive zone cyclostratigraphy (Figure 5). However, two limestone-bearing Van Houten cycles are present above the lowest basalt formation (Mt. Zion Church Basalt) in the basal Midland Formation, suggesting correlation of the latter to the Orange Mountain, Rattlesnake Hill and Talcott basalts. The Hickory Grove Basalt overlies the Midland Formation, and is itself overlain by the Turkey Run Formation, which has one black shale-bearing Van Houten cycle near its base, but is otherwise very poorly known. The Waterfall Formation above the succeeding Sander Basalt is also very poorly known stratigraphically, but is known to have very thick Van Houten cycles, several with a division 2 that is thick and microlaminated (Lindholm, 1979). Based on this poorlyknown stratigraphy, it is not possible to tell exactly where the Hickory Grove and Sander basalts fall within the Newark basin stratigraphy, with one plausible correlation having the Van Houten cycle at the base of the Turkey Run Formation as equivalent to the one in the middle Shuttle Meadow Formation, or having that Van Houten cycle correlating with the weakly-developed cycles in the lower Towaco or Turners Falls formations. In the first case, the Sander Basalt would be the equivalent of the Preakness Basalt, and the Hickory Grove Basalt would belong in the middle Feltville or Shuttle Meadow formations, the correlation favored by Olsen et al. (1996a). In the second case, the Hickory Grove Basalt would correlate with the Preakness Basalt and the Sanders would fall somewhere below the middle Towaco and East Berlin formations. In either case, there is a difference in the basalt stratigraphy between the Culpeper basin and the Newark, Hartford, and Deerfield basins. This differ- ence also shows up in the basalt chemostratigraphy and magnetics (see below).

\subsection{Fundy and Moroccan Basins}

The outcropping Fundy (Nova Scotia and New Brunswick, Canada) and Moroccan basins have cyclical sequences surrounding and interbedded with basaltic lavas that were deposited under much more arid conditions and with much lower accumulation rates, than in the more southern basins (Smoot and Olsen, 1988; Kent and Olsen, 2000b). There is only one basalt formation in the Fundy basin. The North Mountain Basalt lies between the predominately red Blomidon and McCoy Brook formations. There is a thin red, gray, and black cyclical sequence containing the palynologically identified Triassic-Jurassic boundary termed the "Partridge Island member" (Fowell and Traverse, 1995; Olsen et al., $2000,2002 a)$ below the basalt and two limestone-bearing Van Houten cycles overlying the basalt called the Scots Bay Member. Based on the position of the Triassic-Jurassic boundary, Olsen et al. (2002a, 2002c) hypothesized that the uppermost Blomidon Formation cyclical sequence correlates with the Van Houten cycles in the Exeter Township Member of the Passaic formation as shown in Figures 5 and 5. The two obvious Van Houten cycles of the Scots Bay Formation should correlate with the lower Feltville Formation and its equivalents (Figure 5). Thus, based on cyclostratigraphy, the North Mountain Basalt should correlate with the Orange Mountain Basalt and its correlatives in the Newark and more southern outcropping basins.

It is important to note the considerable lateral variations seen in the basal Van Houten cycles in the Feltville, Shuttle Meadow, and McCoy Brook formations of the Newark, Hartford, and Fundy basins. In these three basins, the lowest cycle has at its base a red and green, predominately clastic sequence where the accumulation rate is the highest (e.g., Birney De Wet and Hubert, 1989; Olsen et al., 1989; Olsen et al. 1996a;). However, laterally, in areas of lower accumulation rate, division 2 of the lowest cycle rests directly on the lava, and in some areas the entire lower cycle can be missing. In addition, there are substantial changes in facies laterally in division 2, passing from microlaminated black and gray calcareous shale to massive gray or pink limestones. These lateral variations are important when comparisons are made to isolated sections in the Moroccan basins (see below).

Moroccan Triassic-Jurassic basins south of the Rif (northernmost Morocco, opposite Gibraltar) share many of their lithologic features in outcrop with the Fundy basin, suggesting a preliminary cyclostratigraphic correlation (Figure 5). Sequences remarkably similar to the Partridge Island member of the Fundy basin occur below the lowest basalt in at least the Argana, Khemisset, Berrechid (east of and Khemisset), Bou Fekrane basins and in the and Monts 


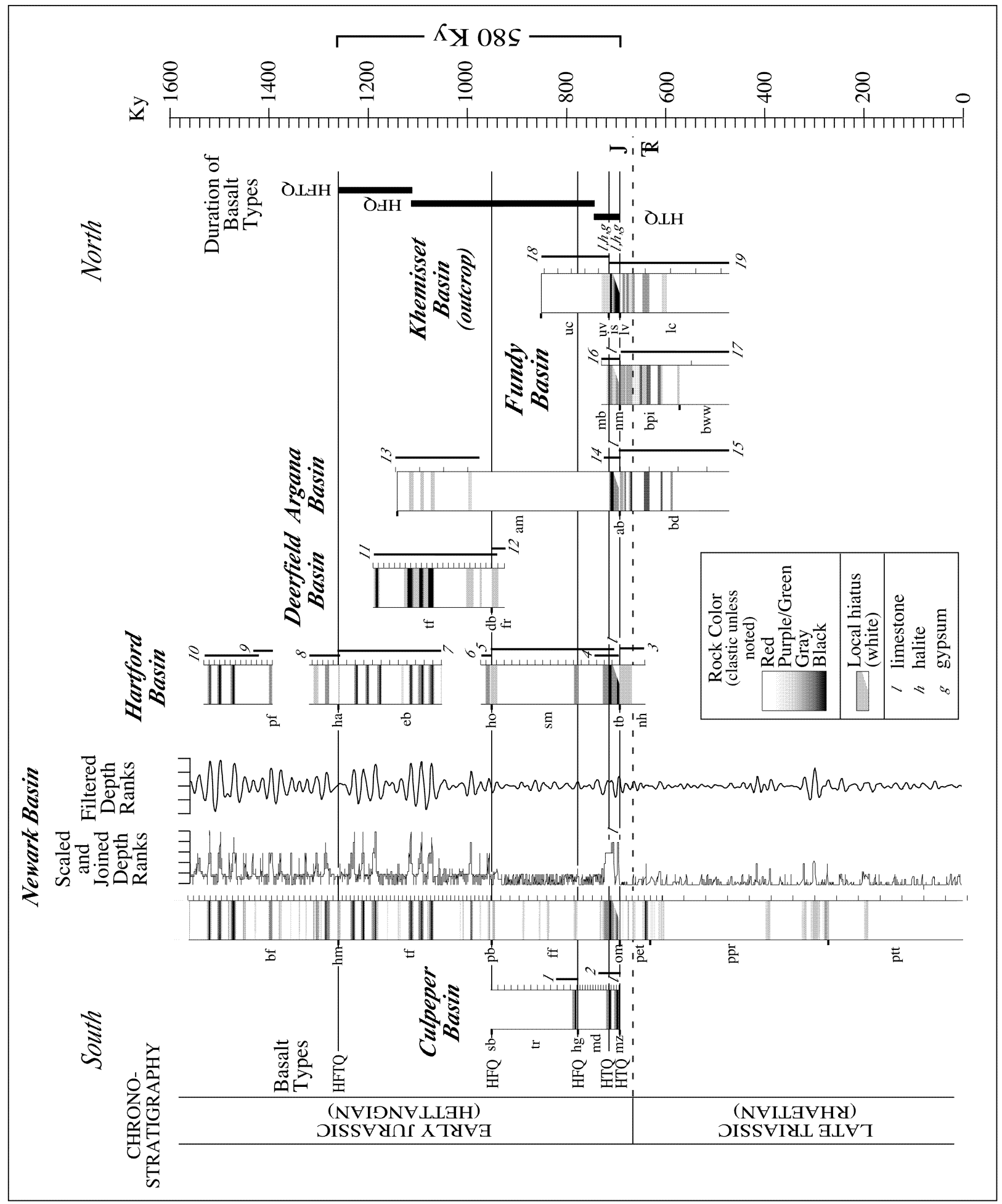


d'Oujda and Beni Snassen (north of Monts d'Oujda) areas. The palynologically-identified Triassic-Jurassic boundary occurs in the same cyclostratigraphic position in at least the Argana basin (Olsen et al, 2000; 2002a, 2002c) relative to the oldest basalt. The stratigraphy and lateral variations (still incompletely known) in the basal carbonate rich sequence above the Argana Basalt and the carbonate-rich sequences between the upper and lower basalt sequences in the Khemisset and Bou Fekrane basins, and in the Beni Snassen and Monts d'Oujda area, are consistent with the limestonebearing Van Houten cycles in the Newark, Hartford, and especially Fundy basins. Based on cyclostratigraphy, and especially these carbonate-rich sequences, the Argana Basalt, and the older basalts in the Khemisset and Bou Fekrane basins, and the lower basalt in the Monts d'Oujda area should correlate with the Orange Mountain Basalt. However, the basalts directly overlying the carbonate-rich cycles in the Khemisset and Bou Fekrane basins and in the Monts d'Oujda area, would seem to correlate with a position above the limestone-bearing Van Houten cycles in the Feltville Formation, and below the rest of the formation (Figure 5).

New geochemical data is available for several key Moroccan basalts, for which we present cyclostratigraphic data (Figure 6, Table 1). These data are in agreement with the cyclostratigraphic data in suggesting a previously unrecognized basalt flow episode of initial Pangean composition
(HTQ of Puffer, 1992; types 1 and 2 of Bertrand et al., 1982) that occurs prior to the eruption of the HFQ type, but after the other known HTQ flows of more southern basins, in at least the Khemisset and Bou Fekrane basins. There is as yet no evidence of basalts of HFQ or LTQ composition in Morocco.

Much of this tentative correlation with Morocco disagrees with published scant biostratigraphy. According to the reviews by Oujidi et al. (2000a. 2000b) and Oujidi and EtTouhami (2000) the lower Khemisset and Bou Fekrane basalts are of Carnian or Ladinian age, and the lower basalt in the Monts d'Oujda area is of Ladinian age, while the upper basalts in the these basins are Carnian and Norian age (see also Oujidi et al., 2000c). This variation in age and the nominal differences between the Argana and Fundy basins is surprising given the close lithological homotaxality of the sequences and their relative proximity to one another. It seems clear that the relative ages of these units will require additional biostratigraphic, magnetostratigraphic, and geochronologic data to work out, although for this paper we clearly favor the cyclostratigraphic arguments.

Of considerable interest is that fact that in the deep parts of the Moroccan basins, notably in the Doukkala, Khemisset, and Berrechid basins, the strata resembling the Partridge Island member of the Fundy basin apparently pass laterally into bedded halite-dominated evaporites (Et-Touhami, 2000; Oujidi, et al., 2000b). In the Doukkala basin, foraminifera

Figure 5. Cyclostratigraphic calibration of the $1.6 \mathrm{~m} . \mathrm{y}$. around the Triassic-Jurassic boundary and CAMP extrusive zone in eastern North America and Morocco. Basin sections are arranged in paleogeographical position showing the distribution of basalt geochemical types, measured sections showing basic lithologies and cyclostratigraphies of individual basin sections. Only the parts of the basin sections for which there is measured cyclostratigraphic data are shown. Basalts are shown as lines with essentially no duration. A, Overall cyclostratigraphic calibration of CAMP basalts.

Formation names are as follows: mz, Mount Zion Church Basalt; md, Midland Formation; hg, Hickory Grove Basalt; tr, Turkey Run Formation; sb. Sander Basalt; ptt, Passaic Formation (member TT); ppg, Passaic Formation (Pine Grove Member); pet, Passaic Formation (Exeter Township Member); om, Orange Mountain Basalt; ff, Feltville Formation; pb, Preakness Basalt; tf, Towaco Formation; hm, Hook Mountain Basalt; bf, Boonton Formation; nh, New Haven Formation; tb, Talcott Basalt; sm, Shuttle Meadow Formation; ho, Holyoke Basalt; eb, East Berlin Formation; ha, Hampden Basalt; pf, Portland Formation; fr, Falls River beds (Sugarloaf Formation); db, Deerfield basalt; tf, Turners Falls Formation; bd, Bigoudine Formation; ab, Argana Basalt; am, Ameskroud Formation; bww, Blomidon Formation ("White Water member"); bpi, Blomidon Formation ("Partridge Island member"); nm, North Mountain Basalt; mb, McCoy Brook Formation; lc, lower clay formation; lv, lower basalt formation; is, interbedded sedimentary unit; uv, upper basalt formation; uc, upper clay formation. Sections are: 1, Turkey Run, Casanova, VA; 2, section formerly exposed at Licking Run Dam, Midland, VA; 3, Cinque Quarry, North Haven, CT; 4, Parmalee Brook at Stagecoach Rd., Durham, CT; 5, US Rt. 1, Branford, CT; 6, small creek south of Bluff Head, Guilford, CT; 7, intersection of State routes 9 and 15, East Berlin, CT; 8, river, stream, and railroad track outcrops adjacent to the Footprint Preserve, Holyoke, MA; 9; railroad cuts and Connecticut River bluffs, near Cedar Knob, northern Holyoke, MA; 10, Stony Brook, East Granby, CT; 11, Rt. 2, Greenfield, MA; 12, Connecticut River, Turners Falls and Gill, MA; 13, Bigoudine, Morocco (Hofmann et al., 2000); 14, Bigoudine, Morocco (same section as 12, but not described by Hofmann et al. (2000); 15, Argana, Morocco (from Olsen et al., 2002c); 16, coves on southeast side of Scots Bay, Nova Scotia (summarized from Birney De Wet and Hubert, 1989 and Olsen et al., 1989); 17, Partridge Island (from Olsen et al., 2002c); 18, well sections described by Tourani et al (1999); 19, section at Nif Gour, Morocco (from Olsen et al., 2002c). 

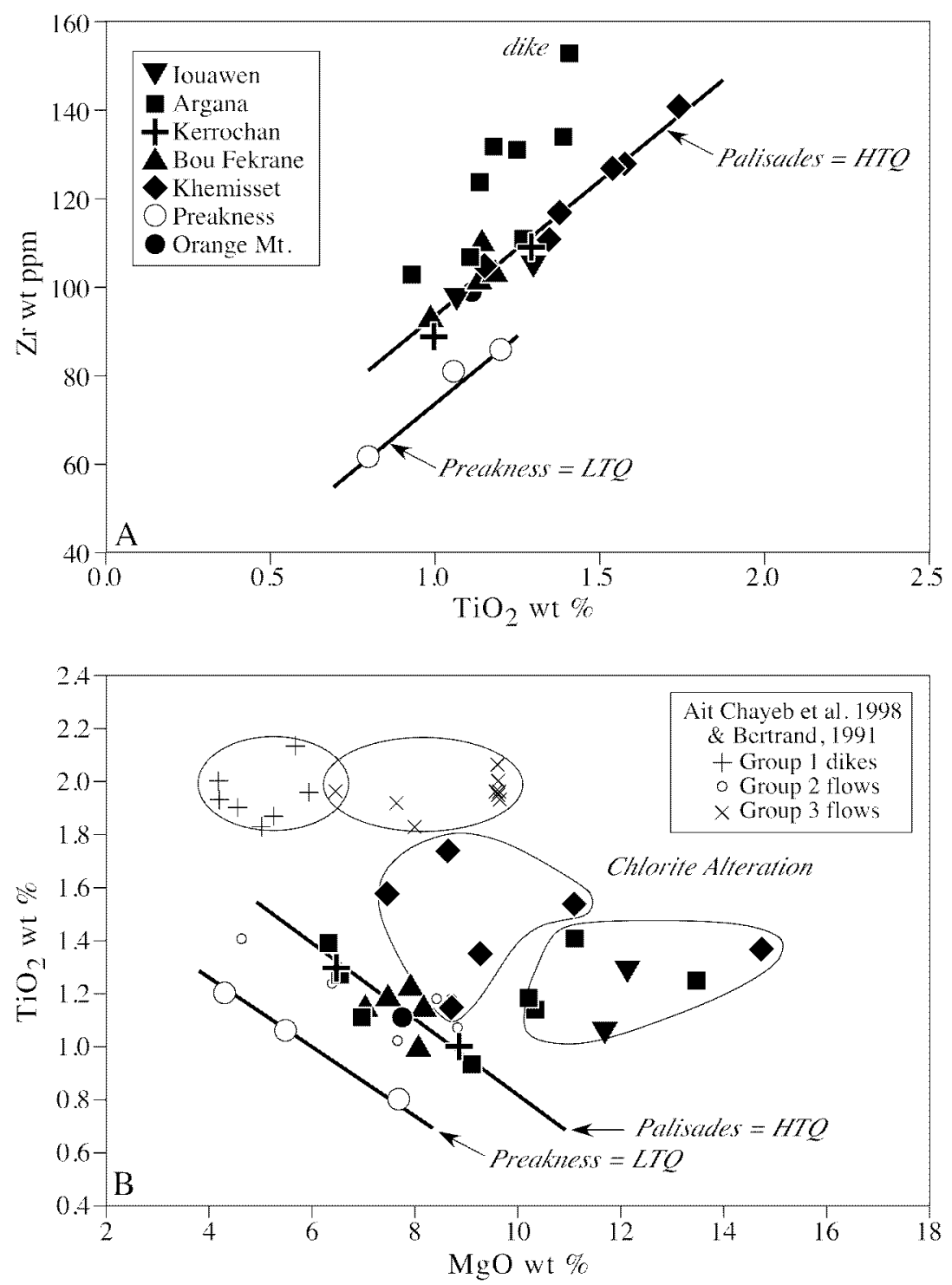

Figure 6. Geochemical data from basalts from Morocco compared to the Palisades/Orange Mountain Basalt (HTQ) trend and the Preakness Basalt (LTQ) trend. Note that, apart from the effects of alteration, all of the new samples lie on the HTQ trend and none lie on the LTQ trend. This includes samples of both lower and upper flow sequences in the Kerrouchen, Bou Fekrane, Khemisset, and Iouawen basins.

indicate that these strata contain the Triassic-Jurassic boundary (Slimane and El Mostaine, 1997), agreeing with the palynological assessment of cyclical red, gray and black strata in the Argana basin. Overlying the basalts in the subsurface of the Berrechid, and Khemisset basins are also halite beds, although their correlation both with the surface and elsewhere is less certain. It is worth noting that the specific pattern of bundling of laterally extensive mud-halite cycles in the salt beds above the basalts in the Berrechide and Khemisset described by Et-Touhami (2000) bear a strong resemblance to the cyclostratigraphy of the Towaco
Formation and its correlatives in eastern North America. More stratigraphic, especially magnetostratigraphic, work is needed to assess the age-significance of this tantalizing similarity, however.

\subsection{Iberia and France: a Marine Connection}

A little known direct connection between CAMP extrusives interbedded with continental strata and probable CAMP lavas extruded into marine Triassic-Jurassic strata is present in six areas in southern Europe. These tholeiitic to alkali basalt flows and pyroclastics occur in southern Iberia, 
Table 1. Geochemical data from Moroccan Basalts.

\begin{tabular}{|c|c|c|c|c|c|c|c|c|c|c|c|c|c|c|}
\hline $\begin{array}{l}\text { Basin } \\
\text { Unit }^{2} \\
\text { Sample\# } \\
\text { Comment } \\
\text { Associated }\end{array}$ & $\begin{array}{l}\text { Kem. } \\
\text { lbst } \\
21-01 \\
\text { ves. } \\
\text { with }^{4}\end{array}$ & $\begin{array}{l}\text { Kem. } \\
\text { ubst } \\
21-02\end{array}$ & $\begin{array}{l}\text { Kem. } \\
\text { ubst } \\
21-03\end{array}$ & $\begin{array}{l}\text { Kem. } \\
\text { lbst } \\
21-16\end{array}$ & $\begin{array}{l}\text { Kem. } \\
\text { lbst } \\
21-18\end{array}$ & $\begin{array}{l}\text { Kem. } \\
\text { ubst } \\
21-20\end{array}$ & $\begin{array}{l}\text { Bou. } \\
\text { lbst } \\
22-07\end{array}$ & $\begin{array}{l}\text { Bou. } \\
\text { ubst } \\
22-08\end{array}$ & $\begin{array}{l}\text { Bou. } \\
\text { lbst } \\
22-11\end{array}$ & $\begin{array}{l}\text { Bou. } \\
\text { lbst } \\
22-19 \\
\text { alt. }\end{array}$ & $\begin{array}{l}\text { Weo, } \\
\text { lbst } \\
22-20 \\
\text { alt. }\end{array}$ & $\begin{array}{l}\text { Weo. } \\
\text { ubst } \\
22-22\end{array}$ & $\begin{array}{l}\text { Ker. } \\
\text { ubst } \\
23-01\end{array}$ & $\begin{array}{l}\text { Ker } \\
\text { lbst } \\
23-02\end{array}$ \\
\hline
\end{tabular}

\begin{tabular}{|c|c|c|c|c|c|c|c|c|c|c|c|c|c|c|}
\hline$\overline{\mathrm{SiO} 2}$ & 52.4 & 51.51 & 52.8 & 52.03 & 53.1 & 51.68 & 52.4 & 51.09 & 51.53 & 52 & 50.46 & 46.2 & 49.23 & 53.3 \\
\hline $\mathrm{TiO} 2$ & 1.58 & 1.38 & 1.15 & 1.54 & 1.74 & 1.35 & 1.14 & 0.99 & 1.14 & 1.18 & 1.3 & 1.07 & 1.0 & 1.29 \\
\hline $\mathrm{Al} 203$ & 13.94 & 10.04 & 13.18 & 11.89 & 13.76 & 13.43 & 14.31 & 14.99 & 14.26 & 14.38 & 11.07 & 13.58 & 13.99 & 14.82 \\
\hline $\mathrm{Fe} 203$ & 9.85 & 9.95 & 10.88 & 10.07 & 9.63 & 10.25 & 9.9 & 9.52 & 10.88 & 10.88 & 11.17 & 9.25 & 10.46 & 9.93 \\
\hline $\mathrm{MnO}$ & 0.16 & 0.16 & 0.18 & 0.17 & 0.16 & 0.17 & 0.17 & 0.16 & 0.18 & 0.18 & 0.18 & 0.16 & 0.17 & 0.16 \\
\hline $\mathrm{TiO} 2$ & 1.58 & 1.38 & 1.15 & 1.54 & 1.74 & 1.35 & 1.14 & 0.99 & 1.14 & 1.18 & 1.3 & 1.07 & 1.0 & 1.29 \\
\hline $\mathrm{MgO}$ & 7.46 & 14.75 & 8.72 & 11.12 & 8.65 & 9.26 & 8.17 & 8.08 & 7.06 & 7.51 & 12.12 & 11.67 & 8.86 & 6.46 \\
\hline $\mathrm{CaO}$ & 9.63 & 6.8 & 10.33 & 8.32 & 9.18 & 10.1 & 10.85 & 11.25 & 10.76 & 10.5 & 8.8 & 11.88 & 11.16 & 10.59 \\
\hline $\mathrm{Na} 20$ & 2.37 & 1.33 & 2.03 & 1.93 & 2.32 & 1.98 & 2.08 & 2.23 & 2.19 & 2.07 & 1.44 & 2.01 & 2.04 & 2.23 \\
\hline K20 & 0.72 & 0.2 & 0.38 & 0.46 & 0.62 & 0.38 & 0.4 & 053 & 0.4 & 0.48 & 0.18 & 0.51 & 0.3 & 0.49 \\
\hline P205 & 0.21 & 0.16 & 0.14 & 0.18 & 0.23 & 0.16 & 0.14 & 0.15 & 0.14 & 0.16 & 0.15 & 0.15 & 0.15 & 0.18 \\
\hline LOI & 2.21 & 3.76 & 0.89 & 1.87 & 0.97 & 1.87 & 0.87 & 0.95 & 0.75 & 1.6 & 2.71 & 3.22 & 2.2 & 1.71 \\
\hline totals & 102.11 & 101.42 & 101.83 & 101.12 & 102.1 & 101.98 & 101.57 & 100.93 & 100.43 & 102.12 & 100.88 & 100.77 & 100.56 & 102.45 \\
\hline
\end{tabular}

Trace Elements (ppm)

\begin{tabular}{|c|c|c|c|c|c|c|c|c|c|c|c|c|c|c|}
\hline $\mathrm{Rb}$ & 18 & & 17 & 26 & 19 & 16 & 21 & 15 & & 14 & 14 & & 14 & 18 \\
\hline $\mathrm{Ba}$ & 170 & & 185 & 190 & 275 & 125 & 115 & 170 & 120 & 183 & 150 & 320 & 310 & \\
\hline $\mathrm{Sr}$ & 237 & 207 & 182 & 256 & 261 & 193 & 174 & 180 & 175 & 176 & 191 & 207 & 178 & 187 \\
\hline $\mathrm{Zr}$ & 128 & 117 & 105 & 127 & 141 & 111 & 110 & 93 & 102 & 103 & 106 & 98 & 89 & 109 \\
\hline $\mathrm{Ni}$ & 86 & 108 & 97 & 104 & 88 & 92 & 108 & 92 & 96 & 94 & 99 & 99 & 86 & 79 \\
\hline $\mathrm{Cr}$ & 247 & 268 & 264 & 303 & 228 & 238 & 357 & 212 & 261 & 229 & 255 & 225 & 217 & 237 \\
\hline
\end{tabular}

Basin Arg. Arg. Arg. Arg. Arg. Arg. Arg. Arg. OMB Preak. Preak. Preak.

Unit flow 7 flow 6 flow 5 flow 4 flow 3 flow 2 flow 1 dike flow 1 flow 1 flow 2 flow 3

$\begin{array}{lllllllll}\text { sample\# } & 27-04 & 27-05 & 27-06 & 27-07 & 27-08 & 27-9 & 27-10 & 27-11\end{array}$

Comment ves. ves. alt.

Associated with zeo. horn. horn.

Major Elements (\%)

\begin{tabular}{|c|c|c|c|c|c|c|c|c|c|c|c|c|}
\hline$\overline{\mathrm{SiO} 2}$ & 53.85 & 50.9 & 52.55 & 55.79 & 50.56 & 46.8 & 49.36 & 48.8 & 52.27 & 53 & 53 & 51 \\
\hline $\mathrm{TiO} 2$ & 1.27 & 0.93 & 1.11 & 1.39 & 1.18 & 1.25 & 1.14 & 1.41 & 1.11 & 1.06 & 1.2 & 0.8 \\
\hline $\mathrm{Al} 203$ & 14.13 & 13.98 & 14.75 & 13.65 & 13.37 & 12.26 & 12.46 & 12.3 & 14.14 & 14.1 & 13.8 & 15.2 \\
\hline $\mathrm{Fe} 203$ & 10.84 & 10.28 & 10.97 & 8.65 & 11.16 & 11.71 & 11.17 & 11.93 & 11.19 & 13.5 & 14 & \\
\hline $\mathrm{MnO}$ & 0.18 & 0.17 & 0.18 & 0.15 & 0.18 & 0.19 & 0.18 & 0.2 & 0.2 & 0.2 & 0.19 & \\
\hline $\mathrm{TiO} 2$ & 1.27 & 0.93 & 1.11 & 1.39 & 1.18 & 1.25 & 1.14 & 1.41 & 1.11 & 1.06 & 1.2 & 0.8 \\
\hline $\mathrm{MgO}$ & 6.54 & 9.11 & 6.98 & 6.32 & 10.2 & 13.45 & 10.33 & 11.09 & 7.75 & 5.5 & 4.3 & 7.7 \\
\hline $\mathrm{CaO}$ & 9.32 & 8.94 & 9.76 & 8.71 & 7.81 & 5.99 & 6.09 & 6.75 & 10.72 & 10 & 9.4 & 10 \\
\hline $\mathrm{Na} 20$ & 2.76 & 2.7 & 2.65 & 3.21 & 3.94 & 3.21 & 4.16 & 3.84 & 2.43 & 3 & 2.8 & 3 \\
\hline K20 & 1.08 & 0.94 & 0.94 & 1.58 & 0.73 & 0.83 & 0.69 & 0.5 & 0.43 & 0.8 & 0.73 & \\
\hline P205 & 0.23 & 0.2 & 0.22 & 0.2 & 0.17 & 0.22 & 0.23 & 0.18 & 0.13 & 0.15 & 0.14 & \\
\hline LOI & 0.81 & 2.22 & 0.88 & 0.75 & 0.86 & 2.51 & 2.18 & 1.37 & & & & \\
\hline totals & 102.28 & 101.3 & 102.1 & 101.79 & 101.34 & 99.67 & 99.13 & 99.78 & & & & \\
\hline
\end{tabular}

Trace Elements (ppm)

\begin{tabular}{|c|c|c|c|c|c|c|c|c|c|c|c|c|}
\hline$\overline{\mathrm{Rb}}$ & 18 & 17 & 17 & 21 & 11 & 17 & 16 & 8 & 15 & 18 & 25 & 8 \\
\hline $\mathrm{Ba}$ & 158 & 174 & 165 & 275 & 240 & 155 & 160 & 80 & & & 179 & \\
\hline $\mathrm{Sr}$ & 185 & 190 & 186 & 238 & 230 & 249 & 207 & 184 & 192 & 140 & 146 & 142 \\
\hline $\mathrm{Zr}$ & 111 & 103 & 107 & 134 & 132 & 131 & 124 & 153 & 99 & 81 & 86 & 62 \\
\hline $\mathrm{Ni}$ & 79 & 92 & 81 & 96 & 89 & 109 & 93 & 110 & 99 & 30 & 25 & 71 \\
\hline $\mathrm{Cr}$ & 201 & 224 & 203 & 248 & 271 & 270 & 249 & 321 & 309 & 30 & 16 & 213 \\
\hline
\end{tabular}

${ }^{1}$ Abbreviations: Kem, Khemisset; Bou, Bou Fekrane; Weo, Weone; Ker, Kerrouchen; Arg., Argana; OMB, Newark basin; Orange Mountain Basalt; Preak, Newark basin, Preakness Basalt.

2 Abbreviations: lbst, lower basalt sequence; ubst, upper basalt sequence.

${ }^{3}$ Abbreviations: ves., vesicular; alt., altered.

4 Abbreviations: zeo., zeolites; horn., ?hornfels.

${ }^{5}$ Dike is very thin $(<30 \mathrm{~cm})$ and wholly within the Argana basalt. 
the Pyrenees of France and Spain, the Aquitaine basin of southwestern France, the Provence area of France, and in the French western Alps.

In southern Iberia, Palain (1977) and Puffer (1993, 1994) describe tholeiitic flows interbedded with red mudstones. In southern Portugal in particular, the St. Bartolomé de Messines section (Palain, 1977) is remarkably similar to that seen in Morocco, especially the Khemessit basin, with two basalt flow sequences separated by a thin limestone sequence that reportedly contains marine Early Jurassic invertebrates (Sopeña et al., 1988).

Flows (and more numerous intrusive sills) occur in the Spanish and French Pyrennes (eastern Corbières) (Azambre et al., 1981; Sopeña et al., 1988), some of which are apparently alkali basalt flows (Azambre and Fabriès, 1989). Most are strongly deformed and altered, but some are fairly fresh. These igneous rocks are probably related to units present in the subsurface in the adjacent Aquitaine basin of France. There, sheets of tholeiitic "ophites" are interbedded within "Keuper" red mudstones and evaporites of apparent Norian age. These are sometimes cited as flows (e.g., Orti Cabo, 1983) but according to Stévaux and Winnock (1974) the under- and overlying strata are metamorphosed near the contact, strongly suggesting they are sills, similar to those in the Pyrenees. However, in the same basin, there are extrusive volcanics that make up a regional marker bed (the tuff of Dubar, 1925) interbedded within Rhaeto-Liassic marine carbonates (Carcans Formation) (Barthe and Stévaux, 1971). The "tuff" is an excellent candidate to be part of the extrusive suite of the CAMP, although detailed study is lacking.

Alkali basalt flows and pyroclastics outcrop in Provence, France, north of Toulon (Lacroix, 1893; Azambre and Fabriès, 1989) and in the Ecrins-Pelvoux (Dauphiné) external massif of the Alps in France (Dumont, 1998; Bainchi et al., 1999). The published biostratigraphic ages of the strata surrounding the alkali basalt flows and pyroclastics in the Ecrins-Pelvoux and Provence areas is Rhaeto-Liassic (Moret and Manquat, 1948; Barthe and Stévaux, 1971; Dumont, 1998), and there are K-Ar dates of 201 and $197 \mathrm{Ma}$ for these, respectively (Baubron, 1974; Baubron in Buffet, 1981). In particular, alkali flows and tuffs in the Dauphiné area are underlain by Triassic dolomites and overlain by fossiliferous Hettangian neritic limestone. According to Moret and Manquat (1948), the most basal of the overlying beds have some invertebrates known from the Rhaetian, but Hettangian forms dominate, and typical Rhaetian forms (e.g., Avicula contorta) are absent. These assemblages clearly require additional study; it is unclear whether they are equivalent to the "pre-planorbis" beds, the traditional basal Hettangian (marked by P. planorbis), or the Rhaetian, although we favor the two former possibilities.
2.5 Offshore Nova Scotia, Grand Banks, and Morocco

CAMP basalt flows have been encountered offshore in wells on the Scotian Shelf and Grand Banks (Pe-Piper et al., 1992; Holser et al., 1988) and offshore Morocco (Oujidi and Et-Touhami, 2000). They are interbedded with evaporites, and thus are closely comparable to basalt occurrences in the deeper parts of the Moroccan basins. However, no details relevant to cyclostratigraphy are available.

\subsection{Brazil}

Lava flows evidently part of the CAMP occur in eastern and southwestern Brazil (Marzoli et al., 1999). The basalts examined by Marzoli et al. (1999) do not seem to occur in Triassic-Jurassic sedimentary basin sequences, although at least one is close to such a sequence (Botucatu Formation) that may be of Triassic or Early Jurassic age (Leonardi, 1994). Thus, no cyclostratigraphic constraints on these deposits exist.

\section{MAGNETOSTRATIGRAPHIC CONSTRAINTS}

Early paleomagnetic studies of the Newark Supergroup basins concentrated mainly on the strongly magnetized basaltic lavas and associated igneous intrusions and found that the rocks carried a predominantly normal polarity magnetization (Dubois et al., 1957; Opdyke, 1961; Irving and Banks, 1961; Beck, 1965, 1972; Larochelle and Wanless, 1966; De Boer, 1967, 1968; Carmichael and Palmer, 1968). These results contributed strongly to the notion of a long normal polarity "superchron" during the Late Triassic and/or Early Jurassic (e.g., Graham interval of McElhinny and Burek, 1971; Newark interval of Pechersky and Khramov, 1973; TRN interval of Irving and Pulliah, 1976), a concept which persists in some recent data compilations (Haq et al., 1988; Johnson et al., 1995; Algeo, 1996). Indeed, with only very few exceptions (e.g., Smith, 1987; Phillips, 1983), virtually all paleomagnetic determinations deemed reliable on hundreds of sampling sites in basaltic lavas and intrusions associated with the Newark Supergroup throughout eastern North America yield normal polarity (e.g., Smith and Noltimier, 1979; Hodych and Hayatsu, 1988; Prevot and McWilliams, 1989).

As summarized by Marzoli et al. (1999), normal polarity is a virtual signature of CAMP tholeiites from the entire circum-Atlantic realm, including South America, West Africa, and southern Europe, as well as eastern North America. As such, CAMP stands alone among flood basalts as having virtually no polarity reversals (i.e., Columbia River, Ethiopian, Greenland, Deccan, Parana, Karoo, Siberian, and Emeishan are each documented to have 2 or more polarity intervals; see references in Courtillot et al., 1999). This may be due to some combination of low reversal 
frequency (e.g., Johnson et al., 1995), remagnetization (e.g., Witte and Kent, 1990), very short duration of the igneous activity (e.g., Olsen et al., 1996b), or inadequate sampling resolution.

The constant normal polarity of the igneous rocks contrasts with the mixed polarities associated with the thick sequence of sedimentary rocks underlying, overlying, and intruded by the Newark igneous rocks (Figure 3), although the sediments interbedded with the basalts are uniformly of normal polarity. As described above, the sediments, usually cyclical and representing about $30 \mathrm{~m} . \mathrm{y}$.. of the Late Triassic, clearly record polarity reversals at an average rate of about 2 per m.y.. (McIntosh et al., 1985; Witte et al., 1991; Kent et al., 1995), similar to the reversal rate in marine sediments of Late Triassic age (Gallet et al., 1992). According to the astronomically tuned GPTS for the Late Triassic based on the Newark data (Kent and Olsen, 1999a), the commencement of consistent normal polarity precedes the basaltic lavas by at most $\sim 1$ m.y. (Chron $23 \mathrm{n}$ ). The very short reverse interval (Chron E23r) immediately underlying the basalts and the Triassic/Jurassic boundary (in Chron E24n) are considerable closer to the basalts ( $>20 \mathrm{ky}$ ) (Olsen et al., 1996a) (Figures 3,5). There is limited exposure of the postextrusive Boonton Formation in the Newark basin which is of normal polarity where sampled (McIntosh et al., 1985; Witte and Kent, 1990). However, we have found what are probably the oldest Hettangian to Sinemurian reversed intervals in the Hartford basin Portland Formation, the older part of which correlates with the Boonton Formation, and there are frequent reversals by the end of the Hettangian and into the Sinemurian in marine sediments of Early Jurassic age from the Paris basin (Yang et al., 1996) (Figures 3, 8). As is the case for the Newark basin the strata interbedded with the flows are of normal polarity (Witte and Kent, 1991). Therefore, the bracketing occurrences of frequent reversals in the Late Triassic and Early Jurassic combined with the estimated length of the Hettangian ( $<4$ m.y. according to the recent time scale of Gradstein et al. [1995]) limit the total duration of any predominantly normal polarity interval in the latest Triassic to earliest Jurassic to less than about 4 million years (Figure 7).

The lavas and intrusions associated with the Newark Supergroup had often been assumed to have been emplaced over a prolonged period, such as from $170 \mathrm{Ma}$ to $204 \mathrm{Ma}$ in the widely used Irving and Irving (1982) paleomagnetic pole compilation, or as two distinct igneous events and corresponding paleopoles at around $175 \mathrm{Ma}$ and $190 \mathrm{Ma}$ (Smith and Noltimier, 1979). However, the Newark Supergroup igneous rocks are now thought more likely to represent a small number of events over a short emplacement episode in the earliest Jurassic $(\sim 201 \mathrm{Ma}$; Sutter, 1988; Dunning and Hodych, 1990). Nonetheless, there is still considerable scatter in the radiometric dates as shown by Marzoli et al. (1999) in which their summary of dates spans some 37 million years (Figure 7), with most dates close to $200 \mathrm{Ma}$.

Some assessment of the geological significance of this scatter in ages can be made by a comparison of the polarity record and the distributions of the actual dates. Using the probability function for all CAMP rocks presented by Marzoli et al. (1999) as a sampling function for smoothing the paleomagnetic record, it is clear that expected frequency of normal polarity for the entire Late Triassic and early part of the Jurassic should be about 0.5 , or $50 \%$ (Figure 7 ). It is not until this sampling interval is compressed to $5 \mathrm{~m} . \mathrm{y}$. or less that we reach the observed $>95 \%$ normal polarity for this probability distribution. Less "peaked" functions would have to be even narrower in their duration. Based on this probabilistic argument, it is likely that the scatter in ages reflects some kind of distortion of the actual crystallization ages by as yet poorly documented geological processes (e.g. Sutter, 1988; Seidemann, 1988, 1991), and thus the cited analytical precession estimates are one to two orders of magnitude greater than the accuracy of the dates. Similarly, it is most likely that most CAMP rocks were emplaced or extruded during chron E 23 or E24, based on this analysis (Figure 7), over an interval of not more than 3 m.y..

\section{BIOSTRATIGRAPHIC CONSTRAINTS}

The most distinctive and perhaps most useful biostratigraphic constraints on the duration of the CAMP basalts is the Triassic-Jurassic boundary. The palynologically identified boundary is marked by the last appearance of many pollen and spore taxa, most importantly the distinctive pollen taxon Patinasporites densus, which is quite common until its last appearance (Cornet, 1977; Cornet and Olsen, 1985; Fowell et al., 1994; van Veen et al., 1995; Fowell and Traverse, 1995). The succeeding survivor assemblage contains few if any first appearances initially, and is characterized by the preponderance of the pollen taxon Corollina meyeriana, which makes its first appearance in eastern North America about 20 m.y. earlier in the Carnian (Cornet, 1977; Cornet and Olsen, 1985).

Cornet (1977) recognized the Passaic-Heidlersburg palynoflora as the uppermost of the biostratigraphic divisions of Triassic age in eastern North America, with its top being the Triassic-Jurassic boundary (Cornet and Olsen, 1985). All of the CAMP lavas in the outcropping basins of eastern North America fall into the succeeding zone of Cornet (1977), the Corollina meyeriana Zone (Cornet and Olsen, 1985). The next zone, the Corollina torosus Zone (Cornet, 1977; Cornet and Olsen, 1985), does not begin until well into the postbasalt formations. 


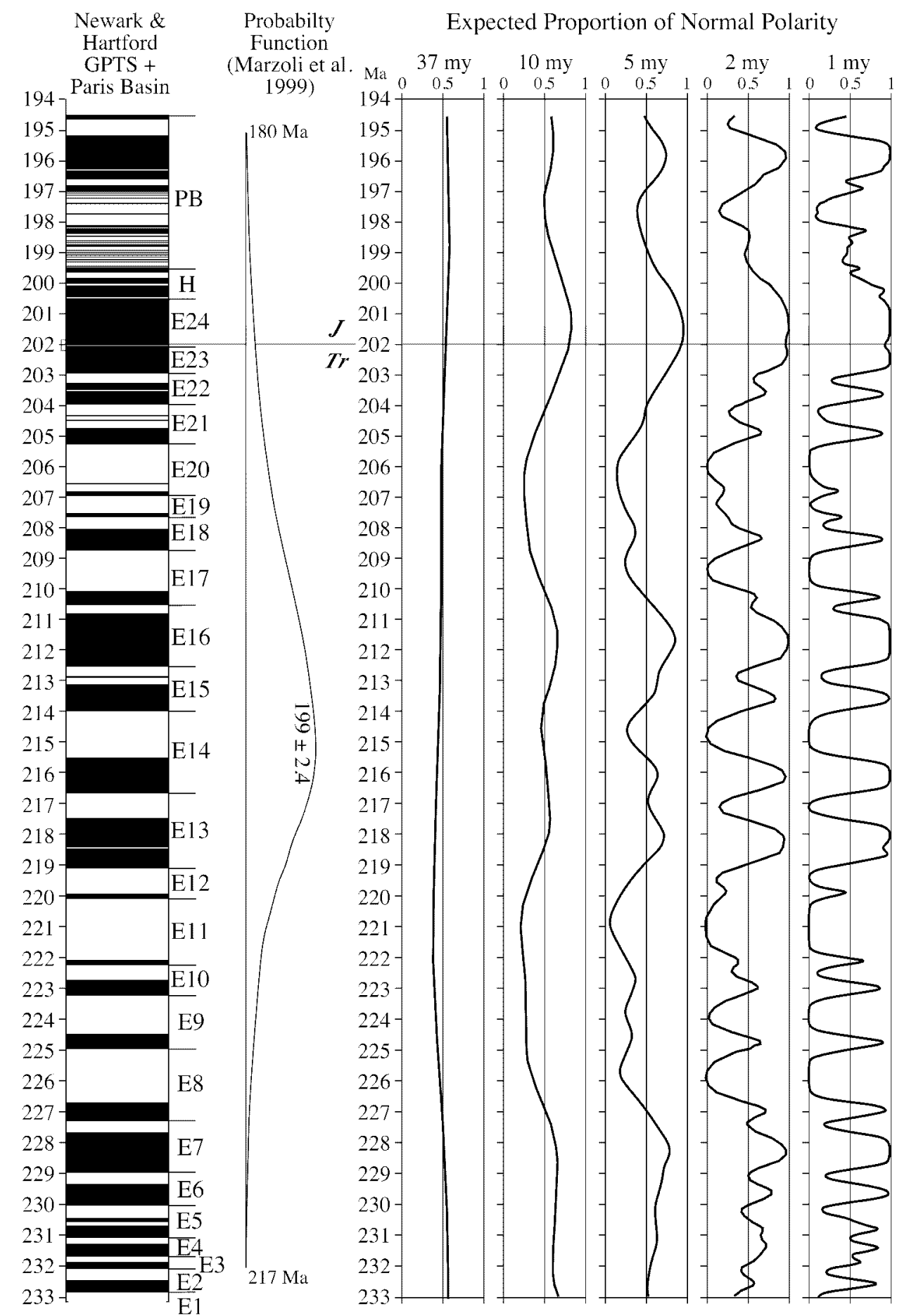

Figure 7. Paleomagnetic constraints on the duration of the CAMP event showing the proportion of the CAMP that would be expected to be of normal polarity if the timing of the emplacement followed the shape of the probability function of Marzoli et al. (1999) with total durations of 37, 10,5,2, and 1 million years. Note that the predicted proportion of normal polarity matches the observed only if the duration of the event is less than 5 m.y.. In Marzoli et al. (1999) this probability function had a total duration of 37 million years (180-217 Ma.) with the maximum probability at $199 \pm 2.4 \mathrm{Ma}$. The probability curves were calculated basically as a moving average with a window shaped as the Marzoli et al. probability function with a lag of $100 \mathrm{ky}$ and with a value of 1 for normal and 0 for reversed polarity in the polarity time scale. The polarity time scale is based on Figure 3 spliced onto the polarity record from the Paris Basin (PB) Early Jurassic of Yang et al. (1996) based on the overlapping Hettangian age portions of the Newark (E1E24) and Hartford $(\mathrm{H})$ polarity records: white is reversed, black is normal, and gray (Hartford basin only) is unsampled (counted here as normal), ages for the Sinemurian based in part on Palfy (2000). 
A major biotic turnover is also seen in vertebrate taxa, both osseous and ichnologic, at or very near the TriassicJurassic boundary (Colbert, 1958; Olsen et al., 1989, 1990; Olsen et al., 2002). The last appearance of the procolophonid parareptile Hypsognathus fenneri occurs in the upper Passaic Formation about two McLaughlin cycles below the Triassic-Jurassic boundary, along with the first appearance of the crocodylomorph cf. Protosuchus sp. (Olsen et al., 2002b). Hypsognathus fenneri is the index fossil of the Cliftonian Land Vertebrate Age (LVA) (Huber et al. 1993). Immediately below the palynologically defined TriassicJurassic boundary are the last appearances of the suchian ichnogenera Brachychirotherium and Apatopus (Szajna and Hartline, 2002; Olsen et al., 2002b), which occur though nearly the entire Late Triassic in eastern North America.

Directly above the palynologically dated boundary occurs the first appearance of the dinosaurian ichnospecies $E u$ brontes giganteus, which is the index fossil for the next LVA, the Wassonian (Lucas and Huber, 2002; Olsen et al., 2002b). All of the CAMP lavas in eastern North America occur within the Wassonian LVA. Within the Wassonian, there is very little taxonomic turnover, with the exception of the appearance of the ornithischian ichnotaxon Anomoepus, in the Feltville Formation and its equivalents (Olsen and Rainforth, 2002), and the prosauropod ichnogenus Otozoum in the East Berlin Formation and its equivalents. The latter taxon so far occurs only in the Hartford basin and north (Rainforth, 2000, 2002).

Thus, all CAMP extrusives in outcropping basins in eastern North America occur within one palynological biozone (Corollina meyeriana Zone) and one Land Vertebrate Age (Wassonian). The Corollina meyeriana Zone is apparently entirely Hettangian in age (Cornet, 1977; Cornet and Olsen, 1985). The Hettangian is widely regarded as the shortest stage of the Jurassic ( $<4$ m.y.; Gradstein et al., 1995; Palfy et al., 2000). While the fact that the CAMP extrusives are limited to a single LVA (Wassonian) is suggestive of a limited time span, the top of the Wassonian is unconstrained and its duration not independently well calibrated. Nonetheless, it is clear that the available biostratigraphic data suggested a short duration for the North American outcropping CAMP extrusives, probably less than 2 m.y..

\section{COMPARISON WITH RADIOMETRIC DATES}

Many radiometric dates, from a variety of systems and vintages (K-Ar, ${ }^{41} \mathrm{Ar} /{ }^{39} \mathrm{Ar}, \mathrm{U}-\mathrm{Pb}, \mathrm{Rb}-\mathrm{Sr}$ ), have been published for igneous rocks included or possibly included within the CAMP. These will not be reviewed here because they have been the subject of recent reviews (Ragland et al., 1992; Marzoli et al., 1999; Hames et al., 2000; Baksi, this volume). However, it is worth noting that the present consensus (e.g. Marzoli et al., 1999) is that the duration of at least most of the CAMP is very brief $(<2$ m.y.) centered on about $200 \mathrm{Ma}$. Indeed, for example, Hames et al. (2000) describe dates from the oldest and youngest basalt flows in the Newark basin (Orange Mountain and Hook Mountain basalts, respectively) that are analytically indistinguishable from one another averaging about $200 \mathrm{Ma}$. However, there are still inconsistencies among dating systems, different laboratories and standards, and even within minerals within the same rock (e.g. Turrin, 2000) that must be reconciled before a real understanding of the geological significance of these dates can be fully realized and approach the precision of astronomical calibration.

\section{RELATIONSHIP OF CAMP TO TRIASSIC-JURASSIC BOUNDARY}

Where evidence is available, all CAMP basalt flows lie above the biostratigraphically identified Triassic-Jurassic boundary, beginning within $20 \mathrm{ky}$ after it based on astronomical calibration (Olsen et al., 1996b, 1999, 2002c). Thus, there is no evidence from superposition that directly allows for CAMP to be the cause of the mass extinctions (Olsen, 1999; Olsen et al., 2002b). Nonetheless, the very close proximity in time is suggestive, and because the outcropping flows are restricted to the northernmost part of the CAMP, it is very possible that a more southerly initiation of this igneous episode occurred prior to the TriassicJurassic boundary (Olsen, 1999; Hames et al., 2000).

There is in fact indirect evidence that at least some CAMP igneous activity might predate the boundary. Given that we do know where at least many of the CAMP basalts fall in the paleomagnetic record, the most likely interval of reversed polarity captured by the CAMP intrusions is the remarkably short E23r (Figures 3, 5, 8). The best known example of a CAMP unit with reversed polarity is one of the north-south trending dikes in North Carolina reported by Smith (1987; site 22). The north-south trending system includes dikes with typical CAMP ages of $-200 \mathrm{Ma}$ (e.g., Ragland et al., 1992), but specific independent confirmation of the CAMP origin of the dike with reversed magnetizations is needed. However, if we accept this dike as CAMP, it most likely indicates some CAMP igneous activity just prior to the Triassic-Jurassic boundary (i.e., during E23r). However, whether the dike was emplaced before or after the boundary, the reversed polarity of this dike definitely indicates that there was some CAMP activity at a different time than all of the studied flows.

Other than the one dike of reported reversed polarity in the Carolina Piedmont (Smith, 1987), the most interesting reported intrusions with reversed polarity are several dikes in Liberia and the Freetown layered intrusion of Sierra Leone. 


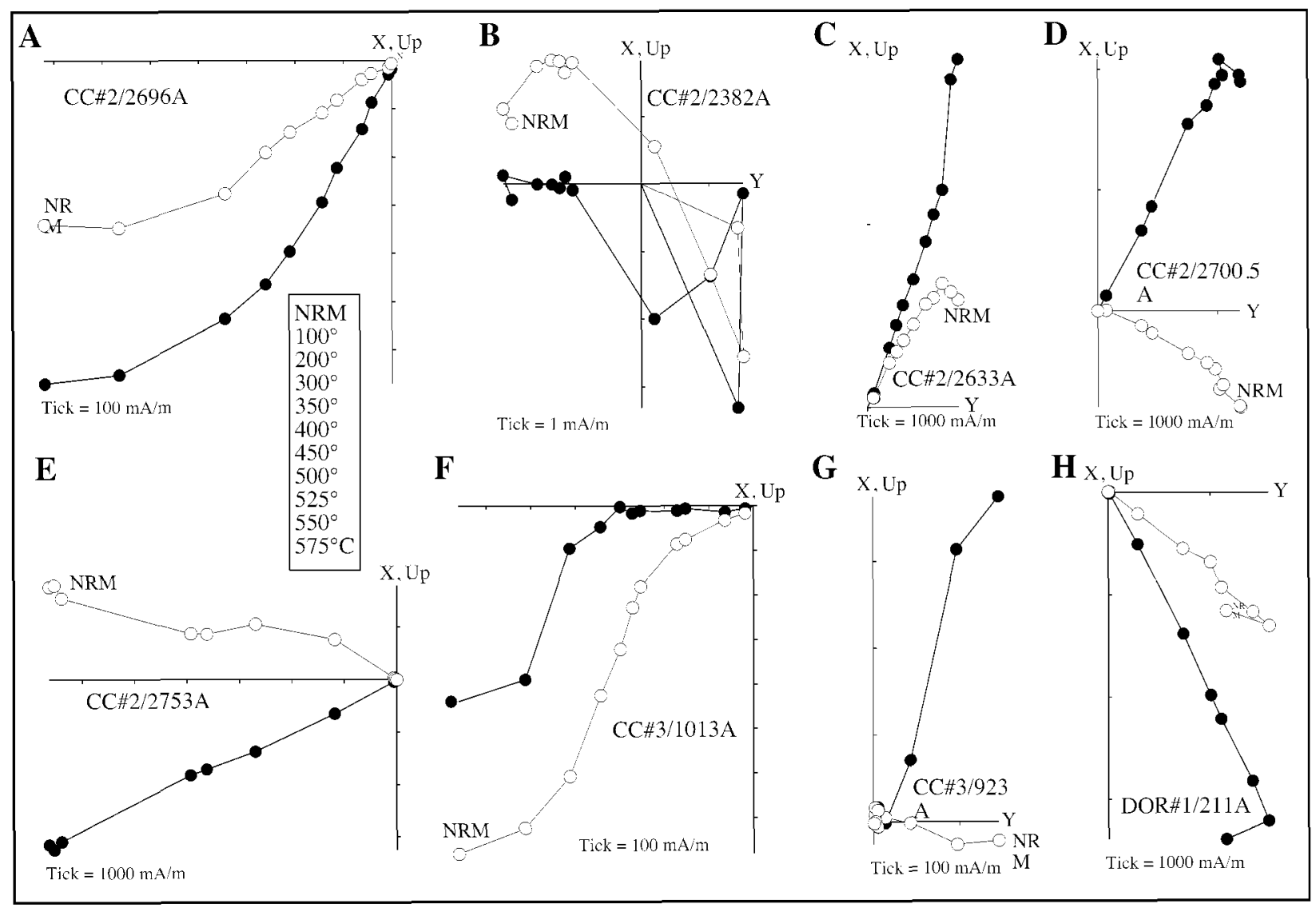

Figure 8. Vector end-point diagrams of NRM thermal demagnetization data from selected samples of Clubhouse Crossroads Basalts from USGS test holes $\mathrm{CCH}$, CC\#3, and DOR\#1. Open/closed symbols are plotted on vertical/horizontal planes where vertical is assumed to be the drill-core axis and the horizontal axes are arbitrary because the drill-core was unoriented with respect to geographic north. List of thermal demagnetization steps applies to all samples. Results of principal component analysis are shown in Table 2.

Dalrymple et al. (1975) reported on $\mathrm{K}-\mathrm{Ar}$ and ${ }^{40} \mathrm{Ar} /{ }^{39} \mathrm{Ar}$ dates and paleomagnetic data from diabase dikes in Liberia. About half of the dikes intruded into Precambrian basement show reversed polarity, while those intruded into younger sedimentary rocks are completely of normal polarity. Pole positions from the two areas of intrusion are indistinguishable and compatible with other west African CAMP poles. Existing $\mathrm{K}-\mathrm{Ar}$ dates are broadly compatible with CAMP (excluding those thought to have excess argon by Dalrymple et al., 1975). If the reversed dikes prove to be part of the CAMP they also indicate some magmatism distinctly older or younger that than the known extrusives of the CAMP.

The Freetown pluton is one of several layered intrusions in west-central Africa. It has a reported Rb-Sr age of $193 \pm 3$ Ma (Beckinsale et al., 1977). Hargraves et al. (1999) report that out of 13 sites they sampled, nine are of reversed and 4 are of normal polarity, which is definitely anomalous com- pared to CAMP. However, according to Hargraves et al. (1999) the magnetization post-dates deformation of the complex intrusion and thus must post-date the intrusion by some amount of time, in agreement with a pole position that would be anomalous for the latest Triassic or earliest Jurassic. Therefore the presence of a significant proportion of reversed polarity has no obvious bearing on the duration of the CAMP event. There are other layered intrusions in the region (Sierra Leone, Liberia, Mali, Guinea, Senegal). The chemistry of these intrusions is compatible with CAMP, and in general newer ${ }^{40} \mathrm{Ar} /{ }^{39} \mathrm{Ar}$ ages of the layered intrusions in the region are appropriate for the CAMP (Diallo, et al., 1992; Deckart et al., 1997). In addition, one of the Guinea intrusions has yielded a U-Pb age of $201.5+/-0.5 \mathrm{Ma}$ (from duplicated fractions of concordant zircon; G. R. Dunning pres. comm., 2000). Thus, these west African layered intrusions are probably part of the CAMP, although their 
magnetizations may post-date the event, and thus provide little information on the duration of the CAMP or their relationship to the Triassic-Jurassic boundary.

Thus, there is some evidence that some of the CAMP may precede the Triassic-Jurassic boundary, and therefore a causal relationship could be possible (Olsen, 1999; Hames et al., 2000) between the two events. However, the best candidate for massive volcanism prior to the TriassicJurassic boundary in the CAMP lies the still largely unconstrained volcanic wedge of seaward dipping reflectors (Holbrook and Kelemen, 1993) that may be volumetrically as large as the rest of the CAMP (Olsen, 1999).

\section{CLUBHOUSE CROSSROADS BASALT, SEAWARD DIPPING REFLECTORS, AND CAMP}

Large areas of the Coastal Plain of southeastern Georgia and South Carolina are underlain by very shallow dipping tholeiitic flows, locally referred to as the Clubhouse Crossroads Basalt, described as interbedded quartz normative and olivine normative basalts (Gottfried et al., 1983; McBride et al, 1989), with most of the observed chemical variation being ascribed to extensive alteration (Gottfried, et al., 1983). These basalts were cored in the early 1980's in three holes by the USGS (CC\#1, CC\#2 and CC\#3 at $\sim 33^{\circ} \mathrm{N}$ $80^{\circ} \mathrm{W}$ ) near Charleston, South Carolina, and have provided both ${ }^{40} \mathrm{Ar}{ }^{39} \mathrm{Ar}$ dates (Lanphere, 1983) and paleomagnetic data (Phillips, 1983). The Clubhouse Crossroad basalts are critical because they have been traced in seismic profiles to the seaward dipping reflectors (SDRs) interpreted as massive edifices of basalt formed during the initial formation of oceanic crust, and are the only direct constraints on the age of the SDRs (McBride et al., 1989; Austin et al., 1990; Holbrook and Kelemen, 1993; Holbrook et al., 1994; Oh et al., 1995; Talwani et al., 1995). The age cited for these basalt flows is generally $184 \mathrm{Ma}$ based on dates by Lanphere (1983), similar to the predicted age of the oldest Atlantic oceanic crust as extrapolated from magnetic anomalies (Klitgord and Shouten, 1986). However, we believe that the radiometric dating and magnetic data that seem to show that the Clubhouse Crossroads Basalt is not part of CAMP are ambiguous, and hence we suggest that the basalts are indeed part the CAMP (as originally thought by Lanphere, 1983), although extensive recoring and redating are required to confirm this. If the Clubhouse Crossroads basalts are part of the CAMP, so may be the seaward dipping reflectors and the age of the transition to oceanic crust may be closer to $200 \mathrm{Ma}$, not $184 \mathrm{Ma}$.

Lanphere (1983) dated three samples of Clubhouse Crossroads Basalt, obtaining whole rock ${ }^{40} \mathrm{Ar} /{ }^{39} \mathrm{Ar}$ incremental release spectra, isochron ages, and total fusion ages.
The incremental heating ages have saddle-shaped spectra, with "plateau" ages of $187 \pm 1.3,161 \pm 3.1$, and $187 \pm 3$, isochron ages of $192 \pm 15.4,167 \pm 2$, and $184 \pm 3.3$, and total fusion ages of $296 \pm 2.9,172 \pm 4.5$, and $182 \pm 2.8$ respectively. Lanphere argued that the most reliable date was the incremental age of $184 \pm 3.3 \mathrm{Ma}$ because of the relatively concordant isochron and total fusion ages of the same sample. Interestingly, Lanphere, also argued that, "this age is in good agreement with reliable ages of tectonically related lower Mesozoic diabase intrusions in eastern North America and Liberia.". The latter ages, of course are now thought to be close to $\sim 200 \mathrm{Ma}$, but the dates on the Clubhouse Crossroads Basalt did agree with the best whole rock ages of similar and older vintage (e.g. Dallmeyer, 1975; Dalrymple et al., 1975; Sutter and Smith, 1979; Seidemann, et al., 1984; Seidemann, 1989). Significantly, Sutter (1988) was able to show that feldspar separates from many eastern North American tholeiites give young ages (175 to $178 \mathrm{Ma}$ ) caused by young, possibly hydrothermal alteration, compared to amphibole and biotite separates from the same rocks (200 to $202 \mathrm{Ma}$ ), suggesting that many whole rock dates, such as those from the Clubhouse Crossroads, may be mixing ages of these two end members (see also Turrin, 2000). Gottfried et al. (1983) indeed described such alteration in these basalts. Whole rock determinations may never be able to accurately date these fine-grained, altered basalts, but additional work on dating mineral separates of single crystals is clearly needed to better constrain accurate radiometric dates of the Clubhouse Crossroads Basalt and understand the origin of the uncertainties.

Phillips (1983) provided NRM and stepwise thermal demagnetization data that suggested the Clubhouse Crossroads Basalt was of mixed magnetic polarity and characterized by relatively high mean (absolute) paleomagnetic inclinations $\left(35^{\circ} \pm 3.2^{\circ}\right)$ indicating a paleolatitude of $19.5^{\circ} \mathrm{N}$. Magnetic polarity results from the NBCP predicts that if it is part of the CAMP, the Clubhouse Crossroads Basalt should be of nearly uniformly normal polarity and should have been extruded close to the equator and hence characterized by much lower paleomagnetic inclinations (e.g. $2-8^{\circ} \mathrm{N}$ ). Superficially, Phillips' results from the Clubhouse Crossroads Basalt would strongly suggest they are not part of the CAMP regardless of their apparent radiometric age. However, Phillips now considers these results as unreliable because of possible core misorientation (pers. comm. in Olsen et al., 1996b). Thus, it is possible that these basalts are of entirely or nearly entirely normal magnetization, and the high paleomagnetic inclinations could be due to unresolved Middle Jurassic or later magnetic overprints.

In order to test this hypothesis we resampled the Clubhouse Crossroads Basalt (USGS CC\#2 and CC\#3 cores) and 


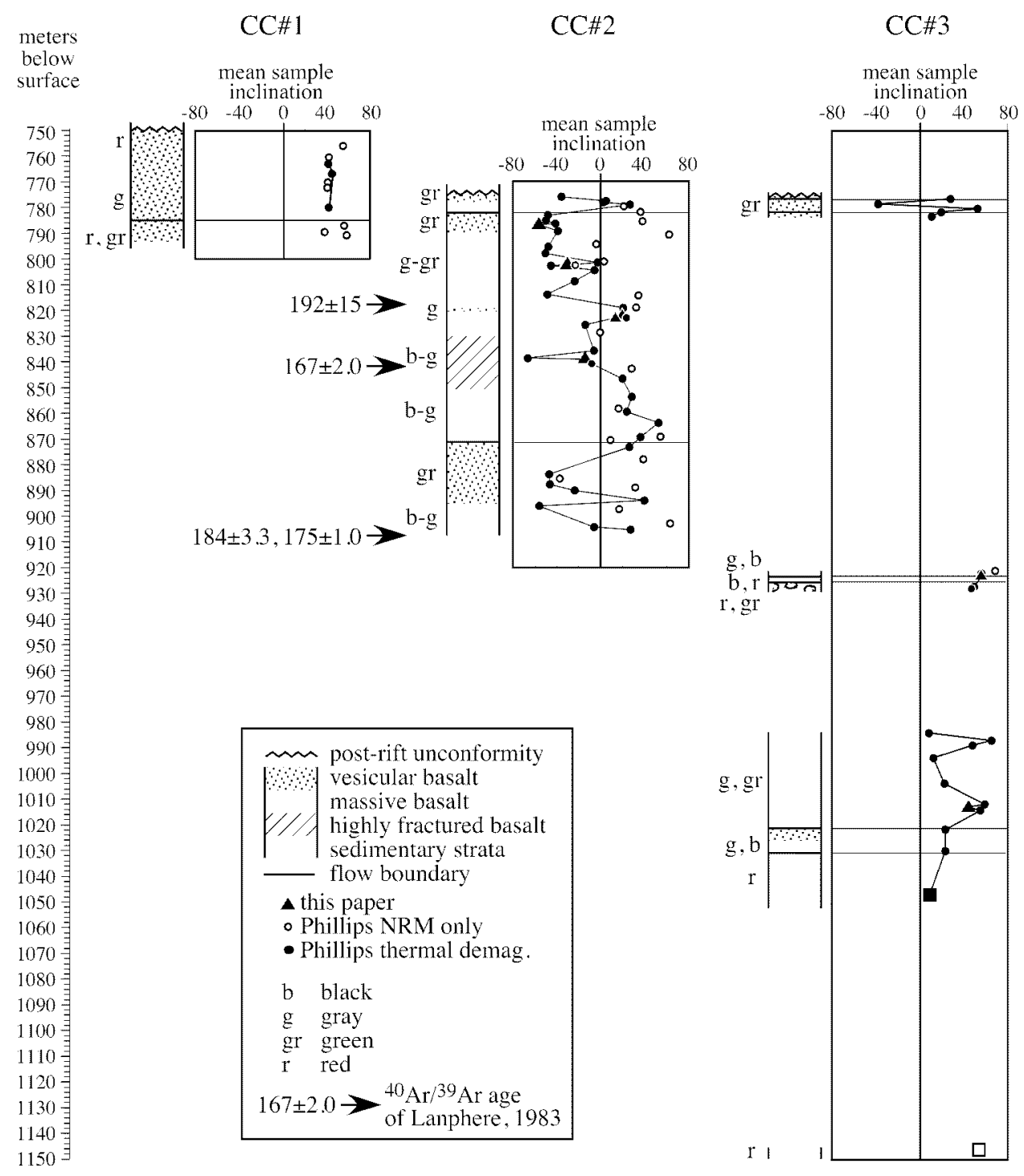

Figure 9. Paleomagnetic data from the Clubhouse Crossroads Basalt from Phillips (1983) and new data from this work plotted on the lithological section of the Clubhouse Crossroads cores from Gottfried et al. (1983).

a basalt encountered in the St. George, South Carolina area (USGS-St. George No. 1 core- DOR-211), and subjected the samples to progressive $\mathrm{AF}$ and thermal demagnetization (Figures 8,9). The results of our analysis on 5 samples from $\mathrm{CC} \# 2$ and 2 samples from $\mathrm{CC} \# 3$ are completely compatible with those of Phillips (1983) including samples with apparent reversed polarity (Figure 9). There is little evidence of a systematic overprint in the thermal demagnetization data (Figure 8). Using the vector isolated between $300^{\circ}$ and $500^{\circ} \mathrm{C}, 3$ of the samples had stable negative inclinations and 3 had stable positive inclinations. One sample (CC\#2/2382A) was judged to be magnetically unstable. The absolute mean inclination of the 6 stable thermally demagnetized sample magnetizations is $28.1^{\circ} \pm 6.3^{\circ}$ (standard error) which is indistinguishable from the $35^{\circ}$ reported by Phillips and consistent with a Middle Jurassic pole (mean sample paleolatitude of $14.9^{\circ} \mathrm{N}$ ) and the radiometric ages of Lanphere (1983).

However, several lines of evidence point towards the possibility of a combination of alteration and core misorientation leading to the apparent differences between CAMP and the Clubhouse Crossroads Basalt. First, with one exception, all of the polarity transitions occur within what Gottfried et al. (1983) identified as single flows (i.e. single cooling units) (Figure 9). For example, based on the thermally demagnetized samples of both Phillips (1983) and our own data, three polarity zones ( 2 reversed and 1 normal) occur in flow 2 of core $\mathrm{CC} \# 2$. One polarity transition in 
particular, at $840 \mathrm{~m}$, occurs in an interval in which Gottfried et al. (1983) specifically says there is, "no indication of any flow boundary". If these two polarity transitions really occur within one flow it implies that cooling of the flow took several thousand years, comparable to the $7.9 \pm 4.5 \mathrm{ky}$ mean duration of Newark polarity transition (Kent and Olsen, 1999a) and estimates of 4 to $10 \mathrm{ky}$ for the Brunhes/Matuyama transition (Clement and Kent, 1984), which seems very unlikely because it would require implausibly slow cooling rates for the individual flows. It seems even more unlikely that such events would be captured by two other flows in the same sequence, one of which is $4.8 \mathrm{~m}$ thick (CC\#3: flow 2). It should be noted that although Gottfried et al. (1983) recognized only 12 flows based on physical and chemical criteria among all three coring sites, Phillips (1983) argued that there are 26 flows based on the paleomagnetic polarity data, that we (and he) believe are unreliable.

Second, there is little correspondence in polarity between what should be the same flows in adjacent cores near the top of each of cored sequence (Figure 9). Because only small portions of the upper part of the flow sequence were cored in $\mathrm{CCH} 1$ and $\mathrm{CCH}$, physical correlation between the flows is speculative. However, the upper parts of all three cores are similar in being highly vesicular and of similar chemistries (Gottfried et al. 1983). In specific, CC\#1 shows no signs of the reversed polarity zones seen in the upper parts of the basalt in $\mathrm{CC} \# 2$ and $\mathrm{CC} \# 3$. Both the first and second points are most easily explained by some of the core segments having been oriented upside down while being boxed - an extraordinarily easy mistake for which we have personal experience. Regrettably, there is no obvious overprint that can be consistently isolated by thermal demagnetization in these cores, preventing a check on their orientation, unlike the Newark basin sedimentary cores that could be oriented post hoc (e. g. Witte and Kent, 1991; Kent et al., 1995).

Third, there appears to be a correlation between the higher (absolute) inclinations and the degree of alteration. In our six samples, the lightest colored (most altered) samples have the steep inclinations (Table 2). These correspond to intervals that Gottfried et al. (1983) argued were highly altered. The least vesicular and darkest (i.e. freshest looking) samples have the lowest inclinations. (Table 2). Although, difficult to test with Phillips' (1983) data, it appears that the higher inclinations again appear to be most often associated with vesicular and altered zones. In addition, in the most altered core sampled (CC\#1: Gottfried et al., 1983), there is essentially no change in inclination from the top to the bottom of the core $(\sim 45 \mathrm{~m})$, including the uppermost samples which are red, vesicular, and soft. It is very difficult to understand how these inclinations can be primary, yet their average of $45.6^{\circ}$ is similar to many of the higher inclination measured throughout the cores. If just the four freshest appearing of our samples are used (DOR\#1/211A; $\mathrm{CC} \# 22753 \mathrm{~A} ; \mathrm{CC} \# 2 / 2700.5 \mathrm{~A} ; \mathrm{CC} \# 2 / 2696 \mathrm{~A}$ ), the mean (absolute) inclination is $16.3^{\circ}$ corresponding to a paleolatitude of $8.3^{\circ} \mathrm{N}$. This compares to an expected inclination for the Clubhouse Crossroads Basalt of $14.8^{\circ}$ (paleolatitude of $7.5^{\circ} \mathrm{N}$ ) for the time during which the Orange Mountain Basalt cooled. Unfortunately, lack of significant time averaging in flows and secular variation makes it very difficult to directly access the meaning of the variation in inclination without additional detailed paleomagnetic, petrographic, and geochemical work (e. g. Witte and Kent, 1990).

We note also that the single red bed result that was subjected to thermal demagnetization by Phillips (1983) has an inclination of $9^{\circ}$, corresponding to a paleolatitude of $4.6^{\circ}$. This compares to the expected inclination of $4.5^{\circ}\left(2.3^{\circ} \mathrm{N}\right.$ paleolatitude) for the Clubhouse Crossroads Basalt based on the Late Triassic-Early Jurassic sedimentary strata in the Newark basin Martinsville core (Kent et al., 1995). We plan to examine these underlying red beds for tests of the origin of the magnetization of the overlying basalts themselves. Thus, we feel that while our new data provide only a slight amount of support for the Clubhouse Crossroads Basalt being part of CAMP, the vagaries and ambiguities in all of the present data allow for that possibility. Moreover, we also argue that the only way to reliably assess the age of the Clubhouse Crossroads Basalt is by additional and much more complete coring and study of these critical basalts themselves.

Oh et al. (1995) argue that the J reflector of Schilt et al. (1983) and Dillon et al. (1983), which is supposedly the signature of the Clubhouse Crossroads Basalt (McBride et al., 1989), overlies the seaward dipping reflectors off the southeastern US. At the present, the Clubhouse Crossroads Basalt is the best constraint on its age. With the radiometric dates and its apparent reversed polarity intervals in question, it is entirely plausible that the seaward dipping reflectors are part of the CAMP event as argued by Withjack et al (1998). Like the rest of the CAMP event, the duration of the emplacement of the seaward dipping reflectors may have been very brief, occurring largely during chron E24n. Indeed Talwani et al. (1995) have argued that the East Coast Magnetic anomaly is a consequence of the volcanic wedge of seaward dipping reflectors being of entirely (or nearly entirely) normal polarity, completely in agreement with its hypothesized origin as part of the CAMP, but not in agreement with the apparent mixed polarity of the Clubhouse Crossroads Basalt to which they are supposed to be tied.

\section{REMAINING CHALLENGES}

Five unresolved issues loom large in the cyclo-, magnetoand bio-stratigraphic constraints on the duration of the 
Table 2. Summary of thermal demagnetization analysis of NRM of selected samples from Clubhouse Crossroads Basalt in USGS drill cores CC\#2, CC\#3, and DOR\#1 near Charleston, South Carolina. Simple arithmetic mean (absolute) inclination of ' $c$ ' component for 7 acceptable samples is $28.1^{\circ}$ with a standard error of $6.3^{\circ}$.

\begin{tabular}{|c|c|c|c|c|c|c|c|c|}
\hline Sample & $\mathrm{Cmp}$ & $\mathrm{N}^{2}$ & Range & $\mathrm{V}^{3}$ & ${ }^{\circ} \mathrm{MAD}^{4}$ & Dec & Inc & Color \\
\hline $\mathrm{CCH} / 2382 \mathrm{~A}$ & $\mathbf{a}$ & 4 & NRM - 300 & $\mathbf{F}$ & $17.8^{*}$ & 173.0 & 54.9 & light green \& \\
\hline $\mathrm{CCH} / 2382 \mathrm{~A}$ & $\mathrm{c}$ & 4 & $300-450$ & A & 3.1 & 179.2 & -56.6 & vesicular \\
\hline $\mathrm{CC} \# 2 / 2633 \mathrm{~A}$ & $\mathbf{a}$ & 4 & NRM- 300 & $\mathbf{F}$ & 5.4 & 277.5 & 1.9 & greenish-brown \& \\
\hline $\mathrm{CC} \# 2 / 2633 \mathrm{~A}$ & c & 5 & $300-500$ & A & 1.6 & 289.5 & -30.1 & vesicular \\
\hline $\mathrm{CCH} 2 / 2696 \mathrm{~A}$ & a & 4 & NRM - 300 & $\mathrm{~F}$ & 8.8 & 155.2 & 16.4 & medium gray \\
\hline $\mathrm{CC} \# 2 / 2696 \mathrm{~A}$ & c & 5 & $300-500$ & A & 1.7 & 118.2 & 18.8 & \\
\hline $\mathrm{CC} \# 2 / 2700.5 \mathrm{~A} a$ & 41 & $N R M-300$ & $F$ & $21.8^{*}$ & $34 . \mathrm{S}$ & 39.1 & dark gray & \\
\hline $\mathrm{CC \# 2/2700.5A} \mathrm{c}$ & 5 & $300-500$ & A & 1.7 & 297.5 & 13.2 & & \\
\hline 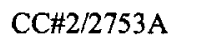 & $\mathbf{a}$ & 4 & NRM - 300 & $\mathrm{~F}$ & 3.5 & 152.7 & -16.1 & dark gray \\
\hline $\mathrm{CC \#} 2 / 2753 \mathrm{~A}$ & c & 5 & $300-500$ & A & 4.7 & 154.4 & -14.2 & \\
\hline $\mathrm{CC} \# 3 / 923 \mathrm{~A}$ & $\mathbf{a}$ & 4 & NRM - 300 & $\mathrm{~F}$ & 3.8 & 287.2 & 4.4 & dark greenish- \\
\hline $\mathrm{CC} \# 3 / 923 \mathrm{~A}$ & $\mathrm{c}$ & 5 & $300-500$ & A & $30.6^{*}$ & 135.1 & 55.9 & gray \\
\hline $\mathrm{CC \# 3/1013A}$ & a & 4 & NRM - 300 & $F$ & 12.6 & 124.2 & 32.5 & greenish-gray \\
\hline $\mathrm{CC} \# 3 / 1013 \mathrm{~A}$ & c & 5 & $300-500$ & A & 7.1 & 175.9 & 44.9 & \\
\hline DOR\#1/211A & $\mathbf{a}$ & 4 & NRM - 300 & $\mathrm{~F}$ & $21.3^{*}$ & 78.0 & 14.6 & black \\
\hline DOR\#1/211A & c & 5 & $300-500$ & A & 1.8 & 63.1 & 19.1 & \\
\hline
\end{tabular}

\footnotetext{
${ }^{1} \mathrm{Cmp}$ is magnetization component described by principal component analysis (Kirschvink, 19801. Low unblocking temperature 'a' components are likely to be overprints; high unblocking temperature ' $c$ ' components are best estimate of characteristic magnetization for each sample.

${ }^{2} \mathrm{~N}$ is number of demagnetization data analyzed over thermal demagnetization interval in ${ }^{\circ} \mathrm{C}$.

${ }^{3} \mathrm{~V}$ is whether best-fit vector is free (F) or anchored (A) to the origin.

${ }^{4} \mathrm{MAD}$ is maximum angular departure (*excluded from overall mean because of high uncertainty); Dec is declination (arbitrary azimuth) and Inc is inclination (assuming drill core axis is vertical and lava flows are horizontal) of best-fit component vector. ${ }^{*} \mathrm{MAD}$ values greater than $15^{\circ}$ indicate poorly resolved component.
}

CAMP event: 1) demonstration, in detail, of how all of the more northern extrusives (Nova Scotia, Scotian Margin, Grand Banks, Morocco, Iberia, and France) fit into the cyclo-, magneto-, and bio-stratigraphy of the TriassicJurassic transition interval; 2) completion of a paleomagnetic census of all of the flows; 3 ) investigation of the stratigraphic constraints on CAMP basalts in South America; 4) description of the relationship between the Clubhouse Crossroads Basalt, the cyclo- and magnetostratigraphy stratigraphy of locally underlying rift strata and the Triassic-Jurassic boundary (if preserved there), and the magnetization of the basalts themselves; and 5) determination of the magnetostratigraphy and age of the seaward dipping reflectors. It is apparent that, while surface work can address issues 1 and 2 in outcropping units, most of these questions will require continuous coring to fully resolve, especially the last two.

\section{CONCLUSIONS}

Based on cyclo-, magneto- and biostratigraphic calibration of the outcropping basalt flows of the CAMP, the duration of igneous activity lasted less than $600 \mathrm{ky}$. Based on the known distribution of normal and reversed polarity zones through the Late Triassic and Early Jurassic, the apparent ages of all CAMP rocks, spanning $>10 \mathrm{~m} . \mathrm{y}$, is not likely to be real, and is likely to be an order of magnitude less. However, the existence of at least some CAMP intrusions of reversed polarity suggest that some igneous activity may have begun prior to the Triassic-Jurassic boundary, and could be involved in the mass-extinctions. The existing data suggesting that the Clubhouse Crossroads Basalt of South Carolina and Georgia is of middle Jurassic age and was not part of the CAMP should probably be discounted pending much additional work. Thus, while the known extent of 
CAMP rocks is very large in area $\left(7 \times 10^{6} \mathrm{~km}^{2}\right)$, its true magnitude may be much greater, because the major volcanic wedge of seaward-dipping reflectors lying off the southeastern US, which is tied to the Clubhouse Crossroads Basalt, may in fact be part of the CAMP as well.

Acknowledgments. Work on this project by Olsen, Et-Touhami, and Kent was funded by grants from the US National Science Foundation to Olsen and Kent (EAR-98-14475 and EAR-9804851), Kent and Olsen (EAR-98-04851, EAR-00-00922), and a grant from the Lamont Climate Center to Olsen. Work in Morocco was aided by logistical support from ONAREP, for which we are very grateful. Et-Touhami was supported during work on this project by a fellowship from the Fulbright Foreign Student Program (MACECE). We thank G. S. Gohn for access to the Clubhouse Crossroads Basalt housed at the USGS in Reston, VA. The paper was reviewed by Emma C. Rainforth, which greatly improved the paper.

\section{REFERENCES}

Ait Chayeb, E. H., Youbi, N., El Boukhari, A., Bouabdelli, M., and Amrhar, M., Le volcanisme permien et mésozoic inférieur du bassin d'Argana IHaut Atlas occidental, Maroc): un magmatisme intraplaque associé à l'overture de l'Atlantique Central. Journal of African Earth Sciences, v. 26, n. 4, p, 499-519, 1998.

Algeo, T. J., Geomagnetic polarity bias patterns through the Phanerozoic, Journal of Geophysical Research, v. 101, p. 27852814, 1996.

Azambre, B. and Fabriès, J., Mesozoic evolution of the upper mantle beneath the eastern Pyrenees; evidence from xenoliths in Triassic and Cretaceous alkaline volcanoes of the eastern Corbières (France), Tectonophysics, v. 170(3-4), p. 213-230, 1989.

Azambre, B., Rossy, M., and Elloy, R., Les dolerites triasiques (ophites) des Pyrenees; donnees nouvelles fournies par les sondages petroliers en Aquitaine, Bulletin de la Societe Geologique de France, v. 23(3), p. 263-269, 1981.

Austin, J. A., Jr., Stoffa, P. L., Phillips, J. D., Oh, J., Sawyer, D. S, Purdy, G. M., Reiter, E., and Makris, J., Crustal structure of the Southeast Georgia Embayment-Carolina Trough; preliminary results of a composite seismic image of a continental suture(?) and a volcanic passive margin, Geology, v. 18, p. 1023-1027, 1990.

Bainchi, G. W., Martinotti, G., Oberhaensli, R. E., Tethys phases of rifting in the realm of the Western Alps; some observations deduced by field and geochemical data. in 4th workshop on Alpine geological studies, edited by .B. Szekely, I. Dunkl, J. Kuhlemann, and W. Frisch, Tuebinger Geowissenschaftliche Arbeiten, Reihe A, Geologie, Palaeontologie, Stratigraphie, v. 52, pp. 127, 1999.

Barthe, A. and Stevaux, J., Le bassin à évaporites du Lias inférieur de l'Aquitaine. Bull. Centre Rech. Pau-SNPA, v. 5(2), p. 363369, 1971.

Baubron, J. C., Sur l'âge triassique du "volcan de Rougiers" (Var).
Méthode potassium-argon, Comptes Rendu Acad Sci., Paris, v. 279D, p. 1159-1162, 1974.

Beck, M. E., Paleomagnetic and geological implications of magnetic properties of the Triassic diabase of southeastern Pennsylvania, Journal of Geophysical Research, v. 70, p. 2845-2856, 1965.

Beck, M. E., Paleomagnetism of Upper Triassic diabase from Pennsylvania: further results, Journal of Geophysical Research, v. 77, p. 5673-5687, 1972.

Beckinsale, R. D., Bowles, J. F. W., Pankhurst, R. J., and Wells, M. K., Rubidium-strontium age studies and geochemistry of acid veins in the Freetown Complex, Sierra Leone, Mineralogical Magazine and Journal of the Mineralogical Society, v. 41, no. 320 , p. 501-511, 1977.

Bertrand, H., The Mesozoic tholeiitic province of Northwest Africa; a volcanotectonic record of the early opening of Central Atlantic, In Magmatism in extensional structural settings; the Phanerozoic African Plate, edited by A. B. Kampunzu, and R. T. Lubala, Springer-Verlag. Berlin, p. 147-188, 1991.

Bertrand, H., Dostal, J., and Dupuy, C., Geochemistry of early Mesozoic tholeiites from Morocco, Earth and Planetary Science Letters, v. 58, 2, p. 225-239, 1982

Birney De Wet, C. C., Hubert, J. F., The Scots Bay Formation, Nova Scotia, Canada, a Jurassic carbonate lake with silica-rich hydrothermal springs, Sedimentology, v. 36(5), p. 857-873, 1989.

Buffet, G., Notice feuille St. Bonnet, Carte géologique de la France à $1 / 50.000$, Coordination M. Gidon, 1981.

Carmichael, C. M. and Palmer, H. C., Paleomagnetism of the Late Triassic, North Mountain basalt of Nova Scotia, Journal of Geophysical Research, v. 73, p. 2811-2822, 1968.

Clement, B. M. and Kent, D. V., A detailed record of the lower Jaramillo polarity transition from a Southern Hemisphere, deepsea sediment core, .Journal of Geophysical Research, B, v. 89, no. 2, p. 1049-1058, 1984.

Colbert, E. H., Tetrapod extinctions at the end of the Triassic period, Proceedings of the National Academy of Sciences of the United States of America, v. 44. p. 973-977, 1958.

Cornet, B., The Palynostratigraphy and Age of the Newark Supergroup, Ph.D. thesis, Pennsylvania State University, University Park, 1977.

Cornet, B. and Olsen, P. E., A summary of the biostratigraphy of the Newark Supergroup of eastern North America, with comments on early Mesozoic provinciality, In Symposio Sobre Flores del Triasico Tardio st Fitografia y Paleoecologia, Memoria. Proc. II) Latin-American Congress on Paleontology (i984), edited by R. Weber, Instituto de Geologia Universidad Nacional Autonoma de Mexico, Mexico City, p. 67-81, 1985.

Courtillot, V., Jaupart, C., Manighetti, I., Tapponnier, P., and Besse, J., , On causal links between flood basalts and continental breakup, Earth and Planetary Science Letters, v. 166, p. 177$195,1999$.

Dallmeyer, R. D., The Palisades sill; a Jurassic intrusion? Evidence from ${ }^{40} \mathrm{Ar} /{ }^{39} \mathrm{Ar}$ incremental release ages, Geology, v. 3, p. 243$245,1975$.

Dalrymple, G. B., Gromme, C. S, and White, R. W., Potassium- 


\section{CONSTRAINTS ON THE DURATION OF THE CAMP EVENT}

argon age and paleomagnetism of diabase dikes in Liberia; initiation of central Atlantic rifting, Geological Society of America Bulletin, v. 86; 3, Pages 399-411, 1975.

De Boer, J., Paleomagnetic-tectonic study of Mesozoic dike swarms in the Appalachians: Journal of Geophysical Research, v. 72 , p. $2237-2250,1967$.

De Boer, J., Paleomagnetic differentiation and correlation of the Late Triassic volcanic rocks in the central Appalachians (with special reference to the Connecticut Valley): Geological Society of America Bulletin, v. 79, p. 609-626, 1968.

Deckart, K., Feraud, G., and Bertrand, H., Age of Jurassic continental tholeiites of French Guyana, Surinam and Guinea; implications for the initial opening of the central Atlantic Ocean, Earth and Planetary Science Letters, v. 150, p. 205-220, 1997.

Diallo, D., Bertrand, H., Azambre, B., Gregoire, M., and Caseiro, J., Le complexe basique-ultrabasique du Kakoulima (GuineeConakry); une intrusion tholeiitique tholeiitique stratifiee liee au rifting de l'Atlantique central, Comptes Rendus de l'Academie des Sciences, Serie 2, Mecanique, Physique, Chimie, Sciences de l'Univers, Sciences de la Terre, v. 314, p. 937-943, 1992.

Dillon, W. P., Klitgord, K. D, and Paull, C. K., Mesozoic development and structure of the continental margin off South Carolina, U.S. Geological Survey Professional Paper 1313, p. N1N16, 1983.

Dubar, J., Le Lias de Pyrénées françaises. Mèm. Soc. Gèol. Nord., v. 9, p. 38-66. 1925.

DuBois, P. M., Irving, E., Opdyke, N. D., Runcorn, S. K., and Banks, M. R., The geomagnetic field in Upper Triassic times in the United States, Nature, v. 180, p. 1186-1187, 1957.

Dumont, T., Sea-level changes and early rifting of a European Tethyan margin in the western Alps and southeastern France, in Mesozoic and Cenozoic sequence stratigraphy of European basins, edited by P.-C. de Gracianshy, J. Hardenbol, T. Jacquin, and P. R. Vail, SEMP Special Publication No. 60, pp. 623-640, 1998.

Dunning, G. R., and Hodych, J. P., U/Pb zircon and baddeleyite ages for the Palisades and Gettysburg sills of the northeastern United States: Implications for the age of the Triassic/Jurassic boundary, Geology, v. 18, p. 795-798, 1990.

Et-Touhami, M., Lithostratigraphy and depositional environments of Lower mesozoic evaporites and associated red beds, Khemisset Basin, northwestern Morocco, in Epicontinental Triassic, Volume 2, edited by G. Bachmann and I, Lerche, Zentralblatt fur Geologie und Palaontologie, VIII, p. 1217-11241. 2000.

Fedosh, M. S., and Smoot, J. P., A cored stratigraphic section through the northern Newark basin, New Jersey, U.S. Geological Survey Bulletin 1776, p. 19-24, 1988.

Fowell, S. J., Cornet, B., and Olsen, P. E., Geologically rapid Late Triassic extinctions: Palynological evidence from the Newark Supergroup, in Pangaea: Paleoclimate, Tectonics and Sedimentation During Accretion, Zenith and Break-up of a Supercontinent, edited by G. D. Klein, Geological Society of America Special Paper 288, p. 197-206, 1994.

Fowell, S. J. and Traverse, A., Late Triassic palynology of the Fundy basin, Nova Scotia and New Brunswick, Review of $\mathrm{Pa}$ laeobotany and Palynology, v. 86, p. 211-233, 1995.

Gallet, Y., Besse, J., Krystyn, L., Marcoux, J., and Theveniaut, H., Magnetostratigraphy of the Late Triassic Bolucektasi Tepe section (southwestern Turkey): Implications for changes in mag- netic reversal frequency, Physics of the Earth and Planetary Interiors, v. 73, p. 85-108, 1992.

Gottfried, D., Annell, C. S., and G. R. Byerly, Geochemistry and tectonic significance of subsurface basalts from Charleston, South Carolina: Clubhouse Crossroads test holes \#2 and \#3, US Geol. Survey Professional Paper 1313, p. A1-A19, 1983.

Gradstein, F. M., Agterberg, F. P., Ogg, J. G., Hardenbol, J., van Veen, P. V., Thierry, J., and Huang, Z., A Triassic, Jurassic and Cretaceous time scale, SEPM Special Publication no. 54, p. 95 126, 1995.

Hames, W. E., Renne, P. R., and Ruppel, C., New evidence for geologically instantaneous emplacement of earliest Jurassic Central Atlantic magmatic province basalts on the North American margin, Geology, v. 28, p. 859-862, 2000.

Haq, B. U., Hardenbol, J., and Vail, P. R., Mesozoic and Cenozoic chronostratigraphy and cycles of sea-level change, Society of Economic Paleontologists and Mineralogists Special Publication, v. 42, p. 71-108, 1988.

Hargraves, R. B., Briden, J. C., and Daniels, B. A., Paleomagnetism and magnetic fabric in the Freetown Complex, Sierra Leone, Geophysical Journal International, v. 136, p. 705-713, 1999.

Heilman, J. J., That catastrophic day in the Early Jurassic, Connecticut Journal of Science Education, v. 25, p. 8-25, 1987.

Hofman, A., Tourani, A., and Gaupp, R., 2000, Cyclicity of Triassic to Lower Jurassic continental red beds of the Argana Valley, Morocco: implications for paleoclimate and basin evolution. Palaeogeography, Palaeoclimatology, Palaeoecology, v. 161, p. 229-266, 2000.

Hodych, J. P., and Hayatsu, A., Paleomảgnetism and $\mathrm{K}-\mathrm{Ar}$ isochron dates of Early Jurassic basaltic flows and dikes of Atlantic Canada, Canadian Journal of Earth Sciences, v. 25, p. 1972$1989,1988$.

Holbrook, W. S. and Kelemen, P. B., Large igneous province on the US Atlantic margin and implications for magmatism during continental breakup, Nature, v. 364, p. 433-437, 1993.

Holbrook, W. S., Reiter, E. C., Purdy, G. M., Sawyer, D., Stoffa, P. L., Austin, J. A., Jr., Oh, J., Makris, J., Deep Structure of the U.S. Atlantic continental margin, offshore South Carolina, from coincident ocean bottom and multichannel seismic data, Journal of Geophysical Research, v. 99(B5), p. 9155-9178, 1994.

Holser, W. T., Clement, G. P., Jansa, L. F., Wade, J. A., Evaporite deposits of the North Atlantic Rift. in Triassic-Jurassic rifting; continental breakup and the origin of the Atlantic Ocean and passive margins, volume $B$, edited by W. Manspeizer, Developments in Geotectonics 22(A-B), p. 525-556, 1988.

Huber, P., Lucas, S. G., Hunt, A. P., Vertebrate biochronology of the Newark Supergroup Triassic, eastern North America, in The Nonmarine Triassic, edited by S. G. Lucas and M. Morales, Bulletin of the New Mexico Museum of Natural History and Science 3, p. 179-186, 1993.

Hubert, J. F. and Dutcher, J. A., Sedimentation, volcanism, stratigraphy, and tectonism at the Triassic-Jurassic boundary in the Deerfield basin, Massachusetts, Northeastern Geology and Environmental Sciences, v. 21, p. 188-201, 1999.

Irving, E. and Banks, M. R., Paleomagnetic results from the Upper Triassic lavas of Massachusetts, Journal of Geophysical Research, v. 66, p. 1935-1939, 1961.

Irving, E. and Irving, G. A., Apparent polar wander paths Carbon- 
iferous through Cenozoic and the assembly of Gondwana, Geophysical Surveys, v. 5, p. 141-188, 1982.

Irving, E. and Pullaiah, G., Reversals of the geomagnetic field, magnetostratigraphy, and relative magnitude of paleosecular variation in the Phanerozoic, Earth Science Reviews, v. 12, p. 35-64, 1976.

Johnson, H. P., Van Patten, D., Tivey, M. A., and Sager, W. W., Geomagnetic polarity reversal rate for the Phanerozoic, Geophysical Research Letters, v. 22, p. 231-234, 1995.

Kent, D. V. and Olsen, P. E., Magnetostratigraphy and paleopoles from the Late Triassic Dan River-Danville basin: interbasin correlation of continental sediments and a test of the tectonic coherence of Newark rift basins in eastern North America, Geological Society of America Bulletin, v. 109(3), p. 366-377, 1997.

Kent, D. V. and Olsen, P. E., Astronomically tuned geomagnetic polarity time scale for the Late Triassic, Journal of Geophysical Research, v. 104, p. 12,831-12,841, 1999a.

Kent, D. V. and Olsen, P. E., Search for the Triassic/Jurassic long normal and the J1 cusp: Eos, Transactions, American Geophysical Union, Supplement, v. 80(46), p. F306, 1999b.

Kent, D. V. and Olsen, P. E., Magnetic polarity stratigraphy and paleolatitude of the Triassic--Jurassic Blomidon Formation in the Fundy basin (Canada): implications for early Mesozoic tropical climate gradients. Earth And Planetary Science Letters, v. 179, no. 2. p. 311-324, 2000a.

Kent, D. V. and P. E. Olsen, Implications of a new astronomical time scale for the Late Triassic, In Epicontinental Triassic, Volume 3, edited by G. Bachmann and I. Lerche, Zentralblatt fur Geologie und Palaontologie, VIII, p. 1463-1474, 2000b.

Kent, D. V., Olsen, P. E., and Witte, W. K., Late Triassic-earliest Jurassic geomagnetic polarity sequence and paleolatitudes from drill cores in the Newark rift basin, eastern North America, Journal of Geophysical Research, v. 100, p. 14,965-14,998, 1995.

Klitgord, K. D. and H. Schouten, Plate kinematics of the central Atlantic, 351-378 pp., Geological Society of America, Boulder, $\mathrm{CO}, 1986$.

Lacroix, A., Les enclaves des roches volcaniques, Ann. Acad. Macon, v. 10, 710 pp., 1893.

Lanphere, M. A., ${ }^{40} \mathrm{Ar} / 39 \mathrm{Ar}$ ages of basalt from Clubhouse Crossroads test hole near Charleston, South Carolina, US Geological Survey Professional Paper 1313, p. B1-B8, 1983.

Larochelle, A. and Wanless, R. K., The paleomagnetism of a Triassic diabase dike in Nova Scotia, Journal of Geophysical Research, v. 71, p. 4949-4953, 1966.

Laskar, J., The chaotic motion of the solar system: a numerical estimate of the size of the chaotic zones. Icarus, v. 88, p. 266$291,1990$.

Laskar, J., The limits of Earth orbital calculations for geological time-scale use. Philosophical Transactions of the Royal Society of London (series A), v. 357, no. 1757, p. 1735-1759, 1999.

Leonardi, G, Annotated atlas of South America tetrapod footprints (Devonian to Holocene), Brasilia, Companhia de Pesquisa de Recursos Minerals, 248 p., 1994.

LeTourneau, P. M. and Huber, P., Early Jurassic eolian dune field, Pomperaug rift basin, Connecticut: implications for Pangean paleoclimate and paleogeography (in review) Sedimentary Geology, 2001.
Lindholm, R. C., Geologic history and stratigraphy of the TriassicJurassic Culpeper Basin, Virginia. Geological Society of America Bulletin v. 90(11), p. I 995-I 997, II 1702-II 1736, 1979.

Lucas, S. G. and Huber, P., Vertebrate Biostratigraphy and Biochronology of the nonmarine Late Triassic, in The Great Rift Valleys of Pangea in Eastern North America, vol .2: Sedimentology, Stratigraphy, and Paleontology, edited by P. M. LeTourneau and P. E. Olsen, Columbia University Press, New York (in press), 2002.

Marzoli, A., Renne, P. R, Piccirillo, E. M., Ernesto, M., Bellieni, G., and De-Min, A., Extensive 200-million-year-old continental flood basalts of the Central Atlantic Magmatic Province, Science, v. 284, p. 616-618, 1999.

McBride, J. H., Nelson, K. D., Brown, L. D., Evidence and implications of an extensive early Mesozoic rift basin and basalt/ diabase sequence beneath the southeast coastal plain, Geological Society of America Bulletin, v. 101, p. 512-520, 1989.

McElhinny, M. W. and Burek, P. J., Mesozoic paleomagnetic stratigraphy, Nature, v. 232, p. 98-102, 1971.

McIntosh, W. C., Hargraves, R. B., and West, C. L., Paleomagnetism and oxide mineralogy of upper Triassic to lower Jurassic red beds and basalts in the Newark Basin, Geological Society of America Bulletin, v. 96, p. 463-480, 1985.

Moret, L. and Manquat, G., Sur un gisement fossilifère remarquable du Lias inférier du Grand Serre, près de Grenoble: Comptes Rendus Somaires Société géologiques France, v. 38, p. 316-317, 1948.

Oh, J., Austin, J. A., Jr., Phillips, J. D., Coffin, M. F., and Stoffa, P. L., Seaward-dipping reflectors offshore the Southeastern United States; seismic evidence for extensive volcanism accompanying sequential formation of the Carolina Trough and Blake Plateau basin, Geology, v. 23p. 9-12, 1995.

Olsen, P. E., Periodicity of lake-level cycles in the Late Triassic Lockatong Formation of the Newark Basin (Newark Supergroup, New Jersey and Pennsylvania). In Milankovitch and Climate, NATO Symposium, Pt. 1, edited by A. Berger, J. Imbrie, J. Hays, G. Kukla, and B. Saltzman, D. Reidel Publishing Co., Dordrecht, p. 129-146, 1984.

Olsen, P. E., A 40-million-year lake record of early Mesozoic climatic forcing. Science, v. 234, p. 842-848, 1986.

Olsen, P. E., Stratigraphic record of the early Mesozoic breakup of Pangea in the Laurasia-Gondwana rift system. Annual Reviews of Earth and Planetary Science, v. 25, p. 337-401, 1997.

Olsen, P. E., Giant Lava Flows, Mass Extinctions, and Mantle Plumes. Science v. 284, no. 5414, p. 604 - 605, 1999.

Olsen, P. E., Cyclostratigraphic controls on the duration and correlation of the Triassic-Jurassic mass extinction and associated basalts, Geological Society of America, Abstracts with Programs, v. 32(1), p. A-63, 2000.

Olsen, P. E, Et-Touhami, M.; Kent, D. V., Fowell, S. J., Schlische, R. W., Withjack, M. O., LeTourneau, P. M., and Smoot, J. P., Stratigraphic, paleoclimatic, and tectonic implications of a revised stratigraphy of the Fundy rift basin, Maritimes, Canada and a comparison with the Argana Rift Basin, Morocco (Triassic-Jurassic), Canadian Journal of Earth Science (in prep.), 2002a.

Olsen, P. E., Fowell, S. J., and Cornet, B., The Triassic-Jurassic boundary in continental rocks of eastern North America: a progress report: in Global Catastrophes in Earth History; an Interdis- 
ciplinary Conference on Impacts, Volcanism, and Mass Mortality, edited by V. L. Sharpton and P. D. Ward, Geological Society of America Special Paper 247, p. 585-593, 1990.

Olsen, P. E. and Kent, D. V., Milankovitch climate forcing in the tropics of Pangea during the Late Triassic. Palaeogeography, Palaeoclimatology, and Palaeoecology, v. 122, p. 1-26, 1996.

Olsen, P. E. and Kent, D. V., Long-period Milankovitch cycles from the Late Triassic and Early Jurassic of eastern North America and their implications for the calibration of the early Mesozoic time scale and the long-term behavior of the planets, Philosophical Transactions of the Royal Society of London (series A), v. 357, p. 1761-1787, 1999.

Olsen, P. E. and Kent D. V., High resolution early Mesozoic Pangean climatic transect in lacustrine environments, in Epicontinental Triassic, Volume 3, edited by G. Bachmann and I, Lerche, Zentralblatt fur Geologie und Palaontologie, v. 1998, $\mathrm{n}^{\circ}$. 11-12, p. 1475-1496, 2000.

Olsen, P. E., Kent, D V., Cornet, B., Witte, W. K., and Schlische, R. W., High-resolution stratigraphy of the Newark rift basin (Early Mesozoic, Eastern North America). Geological Society of America, v. 108, p. 40-77, 1996 a.

Olsen, P. E. and Kent, D. V., Fowell, S. J., Schlische, R. W., Withjack, M. O., and LeTourneau, P. M., Implications of a comparison of the stratigraphy and depositional environments of the Argana (Morocco) and Fundy (Nova Scotia, Canada) Permian-Jurassic basins, in Le Permien et le Trias du Maroc, Actes de la Premièr Réunion su Groupe Marocain du Permien et du Trias, edited by M. Oujidi and M. Et-Touhami, Hilal Impression, Oujda, p. 165-183, 2000.

Olsen, P. E., Kent, D. V., H.-D. Sues, Koeberl, C., Huber, H., Montanari, A., Rainforth, E. C., Fowell, S. J., Szajna, M. J., and Hartline, B. W., Ascent of Dinosaurs Linked to an Iridium Anomaly at the Triassic-Jurassic Boundary, Science, v. 296, p. 1305-1307, 2002b.

Olsen, P. E., Koeberl, C., Huber, H., Montanari, A., Fowell, S. J., EtTouhami, M., and Kent, D. V., The continental TriassicJurassic boundary in central Pangea: recent progress and discussion of an Ir anomaly, Geological Society of America Special Paper (in press), 2002c.

Olsen, P. E., McDonald, N. G., Huber, P., and Cornet, B., Stratigraphy and Paleoecology of the Deerfield rift basin (TriassicJurassic, Newark Supergroup), Massachusetts, in Guidebook for Field Trips in the Connecticut Valley Region of Massachusetts and Adjacent States (vol. 2): New England Intercollegiate Geological Conference 84th Annual Meeting, Contribution no. 66, edited by P. Robinson and J. B. Brady, Department of Geology and Geography, University of Massachusetts, Amherst, Massachusetts, p. 488-535, 1992.

Olsen, P. E. and Rainforth, E., The Early Jurassic ornithischian dinosaurian ichnite Anomoepus. in The Great Rift Valleys of Pangea in Eastern North America, vol .2: Sedimentology, Stratigraphy, and Paleontology, edited by P. M. LeTourneau and P. E. Olsen, Columbia University Press (in press), 2002.

Olsen P. E, Schlische R. W., and Fedosh M. S., 580 ky duration of the Early Jurassic flood basalt event in eastern North America estimated using Milankovitch cyclostratigraphy, in The Continental Jurassic, edited by M. Morales, Museum of Northern Arizona Bulletin 60, p. 11-22, 1996 b.
Olsen, P. E., Schlische, R. W., and Gore, P. J. W. (eds.), Field Guide to the Tectonics, stratigraphy, sedimentology, and paleontology of the Newark Supergroup, eastern North America, International Geological Congress, Guidebook for Field Trips T351, 1989.

Olsen, P. E., Shubin, N. H. and Anders, P. E., New Early Jurassic tetrapod assemblages constrain Triassic-Jurassic tetrapod extinction event, Science, v. 237, p. 1025-1029, 1987.

Olsen, P. E., Sues, H.-D., and Kent, D. V., Constraining the Timing and Magnitude of the Triassic-Jurassic Mass Extinction in Continental Ecosystems. Eos, Transactions, American Geophysical Union, Supplement, v. 80(46), p. F50, 1999.

Opdyke, N. D., The paleomagnetism of the New Jersey Triassic: A field study of the inclination error in red sediments, Journal of Geophysical Research, v. 66, p. 1941-1949, 1961

Orti Cabo, F., Evaporites of the Western Mediterranean, in Triassic of the Mediterranean Region, Volume I, Geological framework, concepts and exploration considerations, edited by G. F. Stewart and J. W. Shelton, and others, ERICO, London, pp. I199-I244, 1983.

Oujidi, M., Courel, L., Benaouiss, N., El Mostaine, M., El Youssi, M., Et Touhami, M., Ouarhache, D., Sabaoui, A. Tourani, A., Triassic series of Morocco: stratigraphy, palaeogeography and structuring of the southwestern peri-Tethyan platform. An overview, in Peri-Tethys Memoir 5: New Data on Peri-Tethyian Sedimentary Basins, edited by S. Crasquin-Soleau and E. Barrier, Mém. mus. natn. Hist. nat., v. 182, p. 23-38, 2000a.

Oujidi, M., Courel, L., Benaouiss, N., El Mostaine, M., El Youssi, M., Et Touhami, M., Ouarhache, D., Sabaoui, A., and Tourani, A., Moroccan palaeogeographic maps during Early Mesozoic times, in Le Permien et le Trias du Maroc, edited by M. Oujidi and M. Et-Touhami, Actes de la Première Réunion du Groupe Marocain du Permien et du Trias, Hilal Impression, Oujda, p. 15-24, 2000b.

Oujidi, M. and Et-Touhami, M., Stratigraphy of Perman and Triassic systems in Morocco: an overview, in Le Permien et le Trias du Maroc, edited by M. Oujidi and M. Et-Touhami, Actes de la Première Réunion du Groupe Marocain du Permien et du Trias, Hilal Impression, Oujda, p. 1-13, 2000.

Oujidi, M., Et-Touhami, M., and Azzouz, O., Contexte géodynamique stratigraphie et sédimentologie des formations triassiques des Monts d'Oujda (Moroc oriental): Livret guide de l'excursion, in Le Permien et le Trias du Maroc, edited by M. Oujidi and M. Et-Touhami, Actes de la Première Réunion du Groupe Marocain du Permien et du Trias, Hilal Impression, Oujda, p. 145-164, 2000c.

Palain, C., Age et paléogéographique de la base du Mésozoiques (Série des Gres de Silves) de l'Agarve-Portugal Meridional. Cuad. Geol. Ibérica, v. 4, p. 259-268, 1977.

Palfy, J., Smith, P. L., Mortensen, J. K., A U-Pb and ${ }^{40} \mathrm{Ar} /{ }^{39} \mathrm{Ar}$ time scale for the Jurassic, Canadian Journal of Earth Sciences, v. 37, p. 923-944, 2000.

Pechersky, D. M. and Khramov, A. N., Mesozoic palaeomagnetism scale of the USSR, Nature, v. 244, p. 499-501, 1973.

Pe-Piper, G., Jansa, L. F., and Lambert, R. St-J., Early Mesozoic magmatism of the Eastern Canadian margin; petrogenetic and tectonic significance, in Eastern North American Mesozoic magmatism, edited by J. H. Puffer and P. C. Ragland, Geologi- 
cal Society of America Special Paper, v. 268, p. 13-36, 1992.

Pienkowski, A. and Steinen, R., P., Geological Society of America, Abstracts with Programs, v. 27(1), p. 74, 1995.

Phillips, J. D., Paleomagnetic investigations of the Clubhouse Crossroads Basalt, US Geol. Survey Professional Paper 1313, p. C1-C18, 1983.

Prevot, M. and McWilliams, M., Paleomagnetic correlation of the Newark Supergroup volcanics, Geology, v. 17, p. 1007-1010, 1989.

Puffer, J. H., Eastern North American flood basalts in the context of the incipient breakup of Pangea. in Eastern North American Mesozoic magmatism, edited by J. H. Puffer and P. C. Ragland, Geological Society of America Special Paper 268, p. 95-118, 1992.

Puffer, J. H., Early Jurassic basalts of the Algarve basin, Portugal: Carboniferous to Jurassic Pangea, Program and Abstracts, Canadian Society of Petroleum Geologists, Annual Convention, Calgary, Canada, Canadian Society of Petroleum Geologists, Calgary, p. 254, 1993.

Puffer, J. H., 1994, Initial and secondary Pangaean basalts, in Pangaea: Global Environments and Resources, edited by A. F. Embry, B. Beauchamp, and D. J. Glass, Canadian Society of Petroleum Geology Memoir 17, p. 85-95, 1994.

Puffer, J. H., and Philpotts, A. R., Eastern North American quartz tholeiites: Geochemistry and petrology, in Triassic-Jurassic rifting; continental breakup and the origin of the Atlantic Ocean and passive margins, volume $B$, edited by $\mathrm{W}$. Manspeizer, Developments in Geotectonics 22(A-B), p. 579-605, 1988.

Ragland, P. C., Cummins, L. E., and Arthur, J. D., Compositional patterns for early Mesozoic diabases from South Carolina to central Virginia, Geological Society of America Special Paper 268, p. 309-331, 1992.

Rainforth, E. C., The Early Jurassic ichnogenus Otozoum, Geological Society of America, Abstracts with Programs, v. 32, no. 1, p. 67, 2000.

Rainforth, E. C., Revision and reevaluation of the Early Jurassic prosauropod ichnogenus Otozoum, Palaeontology (in press), 2002.

Ratcliffe, N. M., Reinterpretation of the relationship of the western extension of the Palisades sill to the lava flows at Ladentown, New York, based on new core data, US Geological Survey Bulletin, v. 1776, p. 113-135, 1988.

Schilt, F. S., Brown, L. D., Oliver, J. E., and Kaufman, S., Subsurface structure near Charleston, South Carolina; results of COCORP reflection profiling in the Atlantic Coastal Plain, US Geological Survey Professional Paper 1313, p. H1-H19, 1983.

Seidemann, D. E., Masterson, W. D., Dowling, M. P., and Turekian, K. K., K-Ar dates and $40 \mathrm{Ar} /{ }^{39} \mathrm{Ar}$ age spectra for Mesozoic basalt flows of the Hartford Basin, Connecticut, and the Newark Basin, New Jersey, Geological Society of America Bulletin, v. 95, p. 594-598, 1984.

Seidemann, D. E., The hydrothermal addition of excess $40 \mathrm{Ar}$ to the lava flows from the Early Juraassic in the Hartford Basin (northeastern U.S.A.): Implications for the time scale, Chemical Geology (Isotope Geoscience Section), v. 72, p. 37-45, 1988.

Seidemann, D. E., Age of the Triassic / Jurassic boundary; a view from the Hartford Basin, American Journal of Science, v. 289, p. 553-562, 1989.
Seidemann, D. E., Comment and reply on "U/Pb zircon and baddeleyite ages for the Palisades and Gettysburg sills of the northeastern United States: Implications for the age of the Triassic/Jurassic boundary", Geology, v. 19, p. 766-767, 1991.

Slimane, A. and El Mostaine, M., Observations biostratigraphiques au niveau des formations rouges del al sèquence synrift dans les bassins de Doukkala et Essaouira. in lém Réunion du Groupe marocain du Permien et du Trias, Oujda, Maroc., Faculté des Sciences, Université Mohammed I, Oujda, p. 54, 1997.

Smith, T. E. and Noltimier, H. C., Paleomagnetism of the Newark Trend igneous rocks of the north central Appalachians and the opening of the central Atlantic Ocean, American Journal of Science, v. 279, p. 778-807, 1979.

Smith, W. A., Paleomagnetic results from a crosscutting system of northwest and north-south trending diabase dikes in the North Carolina Piedmont, Tectonophysics, v. 136, p. 137-150, 1987.

Smoot, J. P.; Olsen, Paul, E., Massive mudstones in basin analysis and paleoclimatic interpretation of the Newark Supergroup. In Triassic-Jurassic rifting; continental breakup and the origin of the Atlantic Ocean and passive margins, volume B, edited by W. Manspeizer, Developments in Geotectonics 22(A-B), p. 249274, 1988.

Sopeña, A., López, J., Arche, A., Pérez-Arlucea, Ramos, A., Virgilli, C. and Hernando, S., Permian and Triassic rift basins of the Iberian Peninsula. In Triassic-Jurassic rifting; continental breakup and the origin of the Atlantic Ocean and passive margins, volume $B$, edited by $\mathrm{W}$. Manspeizer, Developments in Geotectonics 22(A-B), p. 757-786, 1988.

Stévaux, J. and Winnock, E., Les basins du Trias et du Lias inférieur d,Aquitaine et leurs épisodes évaporitiques, Bull. Soc. Géol. France, v. 7a. Sér., 16, p. 679-695, 1974.

Sutter, J. F., Innovative approaches to the dating of igneous events in the early Mesozoic basins of the Eastern United States, US Geological Survey Bulletin 1776, p. 194-200, 1988.

Sutter, J. F., and Smith, T. E., ${ }^{40} \mathrm{Ar} /{ }^{39} \mathrm{Ar}$ Ages of Diabase Intrusions from Newark Trend Basins in Connecticut and Maryland: Initiation of Central Atlantic Rifting, American Journal of Science, v. 279, p. 808-831, 1979.

Szajna, M. J. and Hartline, B. W., A New vertebrate footprint locality from the Late Triassic Passaic Formation near Birdsboro, Pennsylvania, in The Great Rift Valleys of Pangea in Eastern North America, vol 2: Sedimentology, Stratigraphy, and Paleontology, edited by P. M. LeTourneau, P.M. and P. E. Olsen, Columbia University Press, New York (in press), 2002.

Talwani, M., Sheridan, R. E., Holbrook, W. S., and Glover, L., III, The Edge Experiment and the U.S. East Coast Magnetic Anomaly, in Rifted Ocean-Continent Boundary, edited by E. Banda, E., M. Torne, and M. Talwani, Kluwer Academic Publishers, Norwell, p. 155-181, 1995.

Turrin, B. D., ${ }^{40} \mathrm{Ar} / 39 \mathrm{Ar}$ mineral ages and potassium and argon systematics from the Palisade sill, New York, EOS, Transactions, American Geophysical Union, v. 81, no. 48, p. F1326, 2000.

Van Houten, F. B, Cyclic sedimentation and the origin of analcime-rich Upper Triassic Lockatong Formation. west central New Jersey and adjacent Pennsylvania. American Journal of Science, v. 260, p. 561-576., 1962

Van Houten, F. B., Cyclic lacustrine sedimentation, Upper Triassic 
Lockatong Formation, central New Jersey and adjacent Pennsylvania. In Symposium on Cyclic Sedimentation, edited by D. F. Meriam, Kansas Geological Survey Bulletin, v. 169, p. 497-531, 1964.

Van Houten, F. B., Late Triassic Newark Group, north-central New Jersey and adjacent Pennsylvania and New York. In Geology of Selected Areas in New Jersey and Eastern Pennsylvania and Guidebook of Excursions, edited by S, Subitzki, Geol. Soc. Am., Field Trip 4, Atlantic City, NJ. Rutgers University Press, New Brunswick, p. 314-347, 1969.

Van Houten, F. B. Late Triassic part of Newark Supergroup, Delaware River section, west central New Jersey. In Field Studies of New Jersey Geology and Guide to Field Trips, 52nd Annual Meeting, Rutgers University, Newark, NJ. edited by W. Manspeizer, New York. State Geological Association, New York, p. 264-269, 1980.

van Veen, P. M., Fowell, S. J., and Olsen, P. E., Time calibration of Triassic/Jurassic microfloral turnover, eastern North America; discussion and reply, Tectonophysics, v. 245, p. 93-99, 1995.

Withjack, M. O., Schlische, R. W., and Olsen, P. E., Diachronous rifting, drifting, and inversion on the passive margin of Eastern North America: An analog for other passive margins, American Association of Petroleum Geologists Bulletin, v. 82(5A), p. 817 835, 1998.

Witte, W. K. and Kent, D.V., The paleomagnetism of red beds and basalts of the Hettangian Extrusive Zone, Newark Basin, New Jersey, Journal of Geophysical Research, v. 95, p. 17,533$17,545,1990$.

Witte, W. K., and Kent, D. V., Tectonic implications of a remagnetization event in the Newark Basin, Journal of Geophysical Research, v. 96, p. 19,569-19,582, 1991.

Witte, W. K., Kent, D. V., and Olsen, P. E., Magnetostratigraphy and paleomagnetic poles from Late Triassic-earliest Jurassic strata of the Newark Basin, Geological Society of America Bulletin, v. 103, p. 1648-1662, 1991.

Yang, Z., Moreau, M.-G., Bucher, H., Dommergues, J.-L., and Trouiller, A., Hettangian and Sinemurian magnetostratigraphy from Paris Basin, Journal of Geophysical Research, v. 101, p. 8025-8042, 1996. 